\title{
Second-Generation Jak2 Inhibitors for Advanced Prostate Cancer: Are We Ready for Clinical Development?
}

\author{
Paul Beinhoff ${ }^{1}$ D, Lavannya Sabharwal ${ }^{1,2,3}$, Vindhya Udhane ${ }^{1,2,3}$, Cristina Maranto ${ }^{1,2,3}$, Peter S. LaViolette ${ }^{3,4}$, \\ Kenneth M. Jacobsohn ${ }^{3,5}$, Susan Tsai ${ }^{6,7}$, Kenneth A. Iczkowski ${ }^{1,3}$, Liang Wang 3,8 ${ }^{1}$, William A. Hall ${ }^{3,6,9}$, \\ Scott M. Dehm 10,11, Deepak Kilari ${ }^{3,12}$ and Marja T. Nevalainen 1,2,3,*
}

Citation: Beinhoff, P.; Sabharwal, L.; Udhane, V.; Maranto, C.; LaViolette, P.S.; Jacobsohn, K.M.; Tsai, S.; Iczkowski, K.A.; Wang, L.; Hall, W.A.; et al. Second-Generation Jak2 Inhibitors for Advanced Prostate Cancer: Are We Ready for Clinical Development? Cancers 2021, 13, 5204. https://doi.org/10.3390/ cancers13205204

Academic Editor: Constantin N. Baxevanis

Received: 9 September 2021 Accepted: 11 October 2021 Published: 17 October 2021

Publisher's Note: MDPI stays neutral with regard to jurisdictional claims in published maps and institutional affiliations.

Copyright: (c) 2021 by the authors. Licensee MDPI, Basel, Switzerland. This article is an open access article distributed under the terms and conditions of the Creative Commons Attribution (CC BY) license (https:// creativecommons.org/licenses/by/ $4.0 /)$.
1 Department of Pathology, Medical College of Wisconsin Cancer Center, Medical College of Wisconsin, Milwaukee, WI 53226, USA; pbeinhoff@mcw.edu (P.B.); lsabharwal@mcw.edu (L.S.); vudhane@mcw.edu (V.U.); cmaranto@mcw.edu (C.M.); kaiczkowski@mcw.edu (K.A.I.)

2 Department of Pharmacology and Toxicology, Medical College of Wisconsin Cancer Center, Medical College of Wisconsin, Milwaukee, WI 53226, USA

3 Prostate Cancer Center of Excellence at the Medical College of Wisconsin Cancer Center, Medical College of Wisconsin, Milwaukee, WI 53226, USA; plaviole@mcw.edu (P.S.L.); kjacobsohn@mcw.edu (K.M.J.); Liang.Wang@moffitt.org (L.W.); whall@mcw.edu (W.A.H.); dkilari@mcw.edu (D.K.)

4 Department of Radiology, Medical College of Wisconsin Cancer Center, Medical College of Wisconsin, Milwaukee, WI 53226, USA

5 Department of Urology, Medical College of Wisconsin, Milwaukee, WI 53226, USA

6 Department of Surgery, Medical College of Wisconsin Cancer Center, Medical College of Wisconsin, Milwaukee, WI 53226, USA; stsai@mcw.edu

7 Surgical Oncology, Medical College of Wisconsin Cancer Center, Medical College of Wisconsin, Milwaukee, WI 53226, USA

8 Department of Tumor Biology, H. Lee Moffitt Cancer Center, Tampa, FL 33612, USA

9 Department of Radiation Oncology, Medical College of Wisconsin, Milwaukee, WI 53226, USA

10 Masonic Cancer Center, University of Minnesota, Minneapolis, MN 55455, USA; dehm@umn.edu

11 Department of Laboratory Medicine and Pathology, University of Minnesota, Minneapolis, MN 55455, USA

12 Division of Hematology and Oncology, Department of Medicine, Medical College of Wisconsin, Milwaukee, WI 53226, USA

* Correspondence: mnevalainen@mcw.edu; Tel.: +1-414-955-2103

Simple Summary: Prostate Cancer (PC) is currently estimated to affect 1 in 9 men and is the second leading cause of cancer in men in the US. While androgen deprivation therapy, which targets the androgen receptor, is one of the front-line therapies for advanced PC and for recurrence of organconfined PC treated with surgery, lethal castrate-resistant PC develops consistently in patients. PC is a multi-focal cancer with different grade carcinoma areas presenting simultaneously. Jak2-Stat5 signaling pathway has emerged as a potentially highly effective molecular target in PCs with positive areas for activated Stat 5 protein. Activated Jak2-Stat 5 signaling can be readily targeted by the second-generation Jak2-inhibitors that have been developed for myeloproliferative and autoimmune disorders and hematological malignancies. In this review, we analyze and summarize the Jak2 inhibitors that are currently in preclinical and clinical development.

Abstract: Androgen deprivation therapy (ADT) for metastatic and high-risk prostate cancer (PC) inhibits growth pathways driven by the androgen receptor (AR). Over time, ADT leads to the emergence of lethal castrate-resistant PC (CRPC), which is consistently caused by an acquired ability of tumors to re-activate AR. This has led to the development of second-generation anti-androgens that more effectively antagonize AR, such as enzalutamide (ENZ). However, the resistance of CRPC to ENZ develops rapidly. Studies utilizing preclinical models of PC have established that inhibition of the Jak2-Stat5 signaling leads to extensive PC cell apoptosis and decreased tumor growth. In large clinical cohorts, Jak2-Stat5 activity predicts PC progression and recurrence. Recently, Jak2-Stat5 signaling was demonstrated to induce ENZ-resistant PC growth in preclinical PC models, further emphasizing the importance of Jak2-Stat 5 for therapeutic targeting for advanced PC. The discovery of the Jak2V617F somatic mutation in myeloproliferative disorders triggered the rapid development of Jak1/2-specific inhibitors for a variety of myeloproliferative and auto-immune disorders as well as 
hematological malignancies. Here, we review Jak2 inhibitors targeting the mutated Jak2V617F vs. wild type (WT)-Jak2 that are currently in the development pipeline. Among these 35 compounds with documented Jak2 inhibitory activity, those with potency against WT-Jak2 hold strong potential for advanced PC therapy.

Keywords: prostate cancer (PC); anti-androgen resistant prostate cancer; castrate-resistant prostate cancer (CRPC); Janus kinase 2 (Jak2); signal transducer and activator of transcription (Stat); solid tumors

\section{Introduction}

\subsection{Clinical Problem}

Prostate cancer (PC) is currently estimated to affect 1 in 9 men and is the second leading cause of cancer in men in the US [1]. Androgen deprivation therapy (ADT), which targets the androgen receptor (AR), is one of the front-line therapies for systemic PC, which includes metastatic PC and biochemical relapse that has been initially treated surgically or with radiation. ADT, carried out by luteinizing hormone-releasing hormone (LHRH) agonists/antagonists, termed medical castration, reduces the levels of circulating androgens [2-4]. In addition to medical castration, anti-androgens, which are competitive antagonists that bind directly to the AR ligand-binding domain, have been used to control PC growth [2-6].

The first-generation anti-androgen bicalutamide competitively inhibits androgen binding to AR [2-7] and suppresses the recruitment of AR corepressors in PC [7]. The persistent activity of the AR in PC during bicalutamide treatment led to the development of more potent second-generation anti-androgens, such as enzalutamide (ENZ), which has gained increasing dominance in the clinical space and is currently FDA approved as a monotherapy in both pre- and post-chemotherapy settings [8-11]. Second-generation anti-androgens, including ENZ, are more effective competitive inhibitors of steroid binding to the androgen binding pocket on the ligand-binding domain of the AR and retains AR more effectively in the cytoplasmic compartment of PC cells [12]. Apalutamide, another second-generation AR antagonist, recently received FDA approval due to the results of the phase III SPARTAN clinical trial, indicating superior metastasis-free survival and reduced symptomatic progression compared to standard of care [13].

Resistance to ADT results in the development of castrate-resistant prostate cancer (CRPC), which occurs in the vast majority of patients with an average onset of 18-24 months after the initiation of medical castration. Castrate-resistant growth of PC is detected with multiple guiding criteria, including imaging, clinical correlation and rising serum levels of prostate-specific antigen (PSA) [14]. In patients with CRPC resulting from medical castration, ENZ is the first therapeutic option to extend the ADT to tissue-level AR inhibition. ENZ, in turn, provides an improvement in patient survival only by $4-6$ months due to the rapid development of resistance $[9,11,15,16]$. Mechanisms underlying PC resistance to ENZ and other anti-androgens are incompletely understood. The currently proposed mechanisms include the emergence of AR splice variants [17,18], glucocorticoid receptor expression [19], a ligand-binding domain mutation F876L in the AR that promotes an antagonist-to-agonist switch of ENZ [20,21] and neuroendocrine differentiation (NE) [22]. Moreover, the emergence of an AR-null, NE-null PC phenotype driven by the MAPK signaling pathway may contribute to ENZ resistance [23]. The activation of the Jak2-Stat5 signaling pathway has been shown to robustly induce viability and growth of PC cells in vitro and in vivo as tumors in mice. In pre-clinical and PC models and clinical PCs, ENZ-induction of a hyperactivated Jak2-Stat5 signaling feed-forward loop was identified as a novel mechanism of ENZ-resistant PC growth [24]. Activated Jak2-Stat5 signaling can be readily targeted by the current Jak2-inhibitors that have been developed 
for myeloproliferative disorders (MPDs) and hematological malignancies, which will be reviewed here.

\subsection{Jak1/2-Stat Pathway}

\subsubsection{Jak2-Stat5 Signaling Pathway}

Jak2 tyrosine kinase is a member of the Jak family, including Jak1, Jak3 and Tyk2 [25]. Jak2 has seven Jak homology $(\mathrm{JH})$ domains where the JH1 domain represents the kinase domain, $\mathrm{JH} 2$ the pseudokinase domain, the JH3-JH4 domains share homology with $\mathrm{SH} 2-$ domains, and the JH5-JH7 domains represent the FERM domain $[25,26]$. The binding of cytokines, hormones and growth factors to their specific receptors results in receptor multimerization and recruitment of Jak2 by the cytoplasmic domains of these receptors. The conformational change in Jak2 promoted by receptor binding results in transautophosphorylation that involves residues Tyr1007 and Tyr1008, resulting in the activation of Jak2 protein $[25,26]$. Jak2 is the key kinase that phosphorylates Stat5 in PC [27-31]. Stat5 comprises two highly homologous isoforms, Stat5a (94 kDa) and Stat5b (92 kDa) (referred to as Stat5), which are nucleocytoplasmic proteins serving both as cytoplasmic signaling proteins and nuclear transcription factors [32-36]. Upon tyrosine phosphorylation by Jak2, Stat5 forms functional dimers that translocate to the nucleus and bind to specific Stat5 DNA response elements to regulate transcription (Figure 1) [34].

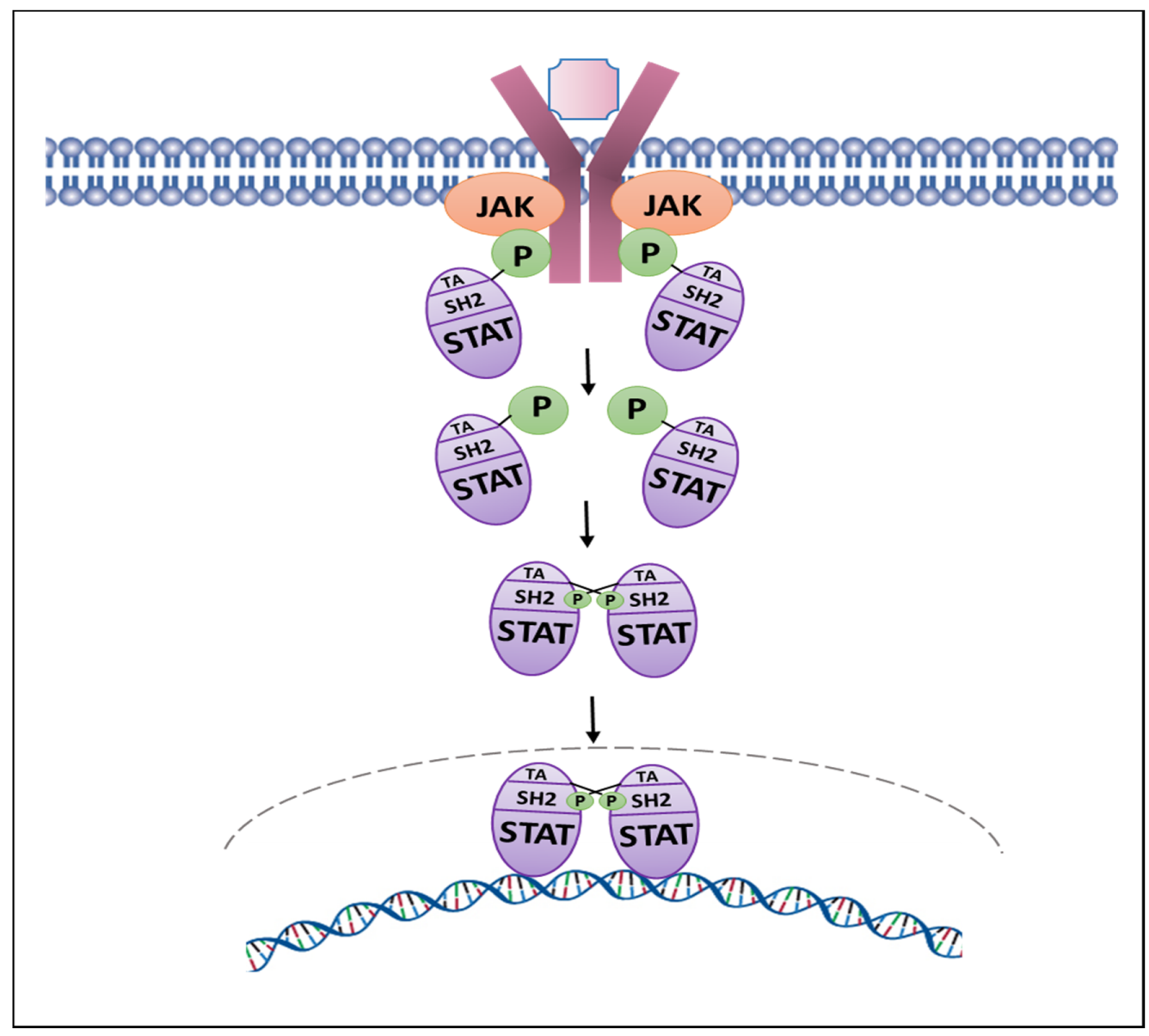

Figure 1. The JAK-STAT pathway. STAT activation is initiated by the binding of an extracellular ligand to trans-membrane receptors, which bring receptor-associated JAKs into close proximity, leading to their activation. The activated JAKs phosphorylate tyrosine residues that serve as docking sites for cytoplasmic STAT transcription factors. STATs bind to JAK through their Src homology 2 (SH2) domain and JAK tyrosine kinases phosphorylate conserved tyrosine residue located between the $\mathrm{SH} 2$ domain and the C-terminal transactivation domain (TA) that result in the formation of STAT dimers, which are stabilized by reciprocal phosphotyrosine and $\mathrm{SH} 2$ domain interactions. Dimerized STAT proteins translocate to the nucleus to regulate the transcription of their target genes. 


\subsubsection{Jak1-Stat3 Signaling Pathway}

In PC, Stat 3 in PC is activated by Jak1 upon IL-6 stimulation. IL- 6 binds to the IL6 receptor, which is a complex composed of two subunits: IL-6-R alpha (IL-6-specific) and gp130 (shared by IL-6 and related cytokines) [37-39]. IL-6 binds to the IL-6R alpha subunit [40], followed by recruitment of the gp130 subunit involved in signal transduction. Association of gp130 with IL-6 and IL-6R alpha forms the high-affinity IL-6 receptor complex leading to activation of the associated Jak1 molecules and phosphorylation of Stat3 on a specific tyrosine residue in the carboxy-terminal domain by a tyrosine kinase [32] In addition, Stat 3 activation is supplemented by phosphorylation of a specific serine residue (S727) [41]. Phosphorylated Stat3 homodimerizes followed by translocation to the nucleus, where it binds to specific Stat3 response elements to regulate transcription [32].

\subsubsection{Transcription Factor Stat5 Induction of Prostate Cancer Growth, Metastatic} Progression and Anti-Androgen Resistance

Stat5 sustains PC cell viability and induces both androgen-sensitive and CRPC growth [30,42-48]. Conversely, blockade of Stat5 signaling induces apoptotic death of PC cells, suppresses the growth of both xenografted and autochthonous PC tumors and induces cell death in clinical patient-derived PCs ex vivo in explant cultures [24,30,42-51]. Overexpression of active Stat5, in turn, has been shown to induce proliferation of PC cells in culture and growth of PC tumors in mice [52]. In addition to PC growth promotion, Stat5 induces metastatic progression of $\mathrm{PC}$, as evidenced by increased epithelial-to-mesenchymal transition and stem-like cancer cell properties through induction of Twist1 and BMI1 expression in PC and promotion of metastasis formation in vivo [30,45]. In 30-40\% of advanced CRPCs, cytogenetic studies have indicated that the chromosome 17 locus encompassing STAT5A and STAT5B genes undergoes amplification in subclones of clinical PCs in histological sections leading to increased Stat5 protein levels [52]. High levels of active Stat5 at the time of the initial PC surgery have been shown to predict PC recurrence in three independent cohorts totaling 1035 patients [53,54]. Intriguingly, combined positive status for both Stat5 gene amplification and high Stat5 protein level was independently associated with shorter disease-free survival in univariate analysis and was an independent predictor of PC recurrence in multivariate analysis when compared to the variables of the Cancer of Prostate Risk Assessment Postsurgical nomogram (CAPRAS) [55]. The predictive role of active Stat5 for clinical PC progression to a lethal CR state [53-55] corroborates the data indicating the involvement of Stat5 in PC progression obtained utilizing preclinical PC models.

In PC cells, the Jak2-Stat5 signaling pathway is activated by a number of growth factors and peptide hormones that are present in serum and expressed and secreted locally in PC tissue in an autocrine/paracrine manner [56-71]. Recently, ENZ-liganded AR was shown to hyperactivate Jak2-Stat5 signaling in CRPC via a mechanism whereby ENZ directly increased activation of both Jak2 and Stat 5 and Stat5 further induced Jak2 mRNA and protein levels. In addition to ENZ-induction of Jak2-Stat5 in preclinical models, Stat5 signaling was elevated in clinical PCs from patients treated with ENZ [24]. Further, ENZliganded AR was shown to induce a rapid and sustained Jak2 phosphorylation in PC cells through a process involving Jak2-specific phosphatases PTP $\varepsilon$ and SHP2 [24]. Importantly, the ENZ-activated Jak2-Stat5 pathway promoted the growth of PC cells during ENZ treatment and, at the same time, inhibition of Stat 5 as a second-line treatment induced extensive death of PC cells surviving ENZ treatment. Most importantly, pharmacological Jak2-Stat5 blockade inhibited CR growth of PC xenograft tumors after ENZ resistance developed and induced further cell death in patient-derived PCs treated with ENZ ex vivo in tumor explant cultures [24]. This work supports a critical role for hyperactive Jak2-Stat5 signaling loop in promoting resistance of PC to ENZ and the need of evaluating the efficacies of Jak2 inhibitors as second-line treatments in advanced PC when ENZ fails. 


\subsubsection{Transcription Factor Stat 3 and Prostate Cancer Growth}

In addition to Stat $5 \mathrm{a} / \mathrm{b}$, Stat 3 has also been implicated in the promotion of growth and PC progression. Stat 3 is activated in advanced stages of PC [72-76], accompanied by the interaction with AR in PC cells [77-80]. In addition, Stat3 has been reported to promote proliferation and inhibit apoptosis in DU145 and LNCaP PC cell lines [72,81-84]. In preclinical PC models, Stat 3 has been shown to increase metastases formation of human PC cells in nude mice, and Stat 3 induced PC cell migration in vitro [84,85]. Interleukin-6 (IL-6) is a multifunctional pre-inflammatory cytokine involved in PC pathogenesis [84,86]. IL- 6 and IL- 6 receptors are expressed in PC $[87,88]$, and IL- 6 has been found to be elevated in the sera of patients with CRPC [89-95]. Moreover, IL-6 is expressed at high levels in the castrate-resistant PC cell lines PC3 and DU145 [94], while the androgen-sensitive PC cell line LNCaP expresses lower IL-6 levels [96]. Many of the current Jak2 inhibitors are also potent inhibitors of Jak1 [84]. Since the IL-6-Jak1-Stat3 pathway is a robust inducer of PC growth and metastasis, simultaneous suppression of Jak1-Stat3 is a desirable off-target effect of the Jak2 inhibitors in therapeutic applications for PC, which would expectedly lead to greater responsiveness of advanced PC to Jak2 inhibitor treatment.

\section{Development of Pharmacological Jak2 Inhibitors: Type I and II Inhibitors}

An activating V617F mutation in the Jak2 pseudokinase domain causes constitutive activation of Jak2 by disrupting the autoinhibitory action of JH2 [97-101]. The Jak2V617F mutation is found in $90-95 \%$ of patients with polycythemia vera (PCV) and $50-60 \%$ of patients with essential thrombocytopenia and myelofibrosis (MF) [97-101]. The discovery and identification of Jak2V617F triggered the development of small-molecule Jak2 inhibitors to specifically target hyperactive mutated Jak2. The main platform for the development of Jak2 inhibitors was structure-based drug design, followed by testing the potency in cell-free kinase assays. These Jak2-inhibitors were designed to target both WT-Jak2 and the mutated Jak2V617F in an ATP-competitive manner occupying the ATP-binding pocket of the active conformation of Jak2 [102]. This Type I mode of inhibition stabilizes the kinase in its active conformation [103]. There is numerous Type I Jak2 inhibitors at various stages of development that differ in structure and specificity against WT-Jak2 vs. mutated Jak2V617F, in addition to differing in selectivity for different Jak family members (Tables 1-3) [102]. Some of the early first-generation Jak1/2 inhibitors were associated with headache, nausea and neurotoxicity, which were likely due to off-target side-effects and penetration through the blood-brain barrier and led to discontinuation of the clinical development [104]. Later, numerous next-generation Type I Jak2 inhibitors were developed with the decreased capability to cross the blood-brain barrier and improved safety profiles. In contrast, Type II Jak2 inhibitors were designed to bind Jak2 in the inactive conformation, where the inhibitor occupies the ATP binding site and induces a hydrophobic pocket stabilizing the inactive conformation [103]. However, Type II Jak2 inhibitors are not in clinical development.

Table 1. JAK Family Inhibitors in Clinical Development.

\begin{tabular}{|c|c|c|c|c|c|}
\hline Drug Name & Mechanism & Indication & NCT \# & $\begin{array}{l}\text { Trial } \\
\text { Phase }\end{array}$ & Outcome \\
\hline \multirow[t]{5}{*}{$\begin{array}{l}\text { Ruxolitinib * } \\
\text { (FDA approved) }\end{array}$} & $\begin{array}{c}\text { Jak1 }>\text { Jak2 > Tyk2 > } \\
\text { Jak3 } \\
\text { inhibitor (Type 1) }\end{array}$ & Prostate cancer & NCT 03274778 & $\mathrm{~N} / \mathrm{A}$ & $\begin{array}{l}\text { Withdrawn: Recruitment } \\
\text { difficulty }\end{array}$ \\
\hline & & $\begin{array}{l}\text { Refractory malignant solid } \\
\text { neoplasm }\end{array}$ & NCT 03878524 & 1 & Recruiting \\
\hline & & $\begin{array}{l}\text { Androgen-independent prostate } \\
\text { cancer }\end{array}$ & NCT 00638378 & 2 & Terminated: Low efficacy \\
\hline & & Prostate cancer & NCT 03274778 & $\mathrm{~N} / \mathrm{A}$ & $\begin{array}{c}\text { Withdrawn: Recruitment } \\
\text { difficulty }\end{array}$ \\
\hline & & Solid tumors (including prostate) & NCT 02711137 & $1 / 2$ & Terminated \\
\hline \multirow{2}{*}{$\begin{array}{c}\text { Fedratinib * } \\
\text { (FDA approved) }\end{array}$} & $\begin{array}{l}\text { Jak2 inhibitor } \\
\text { (Type } 1 \text { ) [106] }\end{array}$ & Solid tumors & NCT 01836705 & 1 & Completed \\
\hline & & Solid tumors & NCT 01585623 & 1 & Completed \\
\hline \multirow[t]{2}{*}{ Pacritinib * } & Jak2 (Type 1) [107] & $\begin{array}{l}\text { MF, PCV, post-essential } \\
\text { thrombocythemia MF }\end{array}$ & NCT 02055781 & 3 & Terminated (FDA concerns) \\
\hline & & $\begin{array}{l}\text { MF, PCV, post-essential } \\
\text { thrombocythemia MF }\end{array}$ & NCT 03165734 & 3 & Recruiting \\
\hline
\end{tabular}


Table 1. Cont.

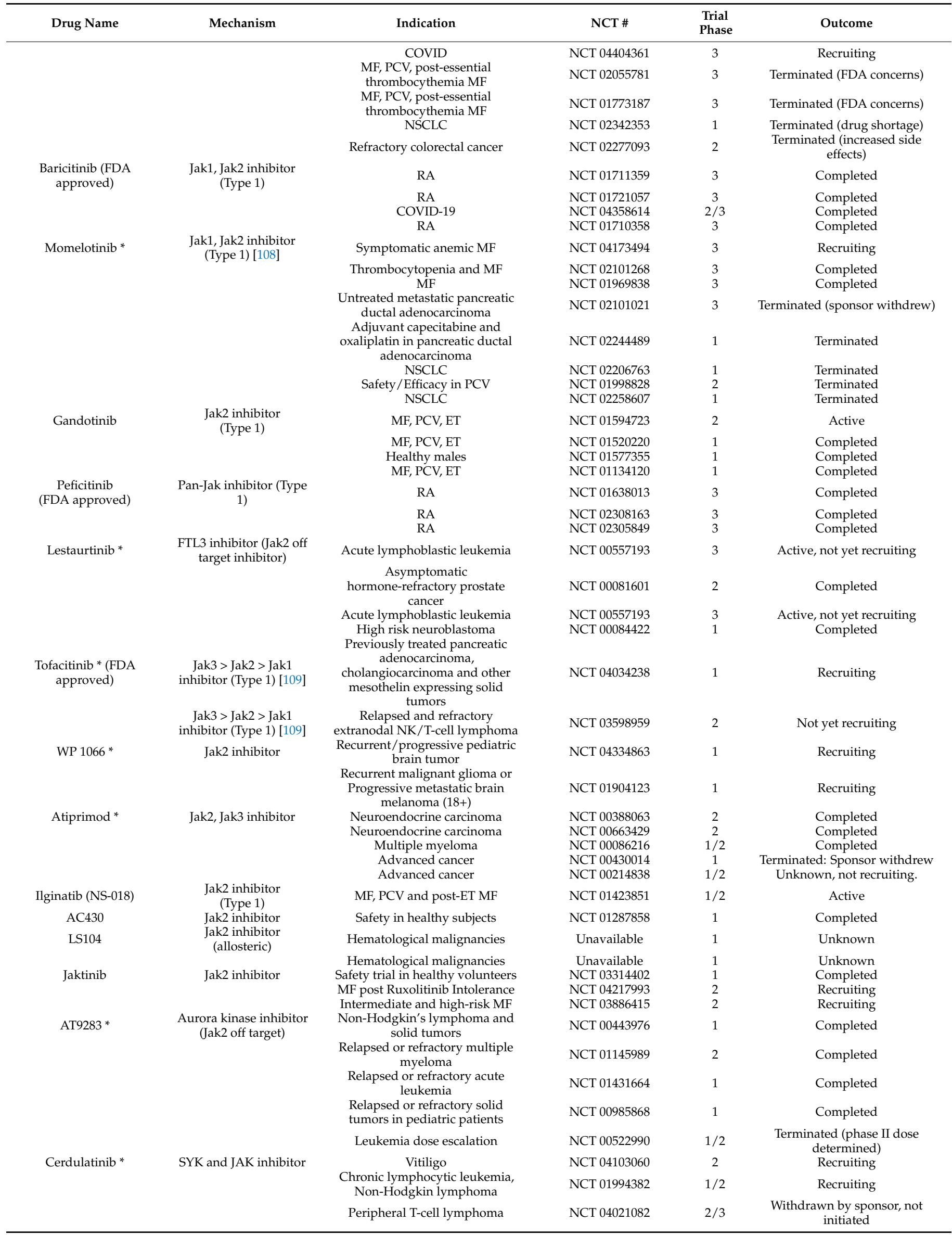


Table 1. Cont.

\begin{tabular}{|c|c|c|c|c|c|}
\hline Drug Name & Mechanism & Indication & NCT \# & $\begin{array}{l}\text { Trial } \\
\text { Phase }\end{array}$ & Outcome \\
\hline \multirow[t]{2}{*}{$\begin{array}{c}\text { Filgotinib } \\
\text { (FDA approved) }\end{array}$} & \multirow[t]{2}{*}{$\begin{array}{l}\text { Jak1 inhibitor } \\
\text { (Type 1) }\end{array}$} & Ulcerative colitis & NCT 02914522 & 3 & Completed \\
\hline & & $\begin{array}{c}\text { RA } \\
\text { RA } \\
\text { RA } \\
\text { Testicular safety }\end{array}$ & $\begin{array}{l}\text { NCT } 02873936 \\
\text { NCT } 02886728 \\
\text { NCT } 02889796 \\
\text { NCT } 03201445\end{array}$ & $\begin{array}{l}3 \\
3 \\
3 \\
2\end{array}$ & $\begin{array}{l}\text { Completed } \\
\text { Completed } \\
\text { Completed } \\
\text { Recruiting }\end{array}$ \\
\hline \multirow[t]{3}{*}{ Decernotinib } & \multirow{3}{*}{$\begin{array}{l}\text { Jak3 inhibitor } \\
\text { (Type 1) } \\
\text { Jak3 inhibitor } \\
\text { (Type 1) }\end{array}$} & RA & NCT 01830985 & $2 / 3$ & Completed \\
\hline & & Healthy subjects & NCT 01886209 & 1 & Completed \\
\hline & & $\begin{array}{c}\text { RA } \\
\text { RA } \\
\text { Healthy subjects } \\
\text { RA }\end{array}$ & $\begin{array}{l}\text { NCT } 01886209 \\
\text { NCT } 01590459 \\
\text { NCT } 00789126 \\
\text { NCT } 01052194\end{array}$ & $\begin{array}{l}2 \\
2 \\
1 \\
2\end{array}$ & $\begin{array}{l}\text { Completed } \\
\text { Completed } \\
\text { Completed } \\
\text { Completed }\end{array}$ \\
\hline \multirow[t]{8}{*}{ Erlotinib * } & \multirow[t]{8}{*}{$\begin{array}{l}\text { EGFR inhibitor (Jak2 off } \\
\text { target inhibitor) }\end{array}$} & $\begin{array}{l}\text { Chemo-naive, androgen } \\
\text { independent prostate cancer }\end{array}$ & NCT 00272038 & 2 & Completed \\
\hline & & $\begin{array}{l}\text { Adjuvant bevacizumab in } \\
\text { prostate cancer }\end{array}$ & NCT 00203424 & 2 & Completed \\
\hline & & $\begin{array}{l}\text { Non-metastatic prostate cancer } \\
\text { with rising PSA }\end{array}$ & NCT 00148772 & 2 & Completed \\
\hline & & $\begin{array}{l}\text { Adjuvant docetaxel in older } \\
\text { patients with prostate cancer }\end{array}$ & NCT 00087035 & 2 & Completed \\
\hline & & $\begin{array}{l}\text { Solid tumors and liver/kidney } \\
\text { dysfunction }\end{array}$ & NCT 00030498 & 1 & Completed \\
\hline & & Dose escalation study & NCT 00739453 & $1 b$ & Completed \\
\hline & & $\begin{array}{l}\text { Drug combination study in } \\
\text { various cancers }\end{array}$ & NCT 03878524 & 1 & \\
\hline & & $\begin{array}{l}\text { Adjuvant bevacizumab in } \\
\text { hormone refractory prostate } \\
\text { cancer }\end{array}$ & NCT00996502 & $1 / 2$ & Terminated \\
\hline \multirow[t]{4}{*}{ Givinostat* } & \multirow[t]{4}{*}{ HDAC inhibitor } & R/R Hodgkin's lymphoma & NCT 00792467 & $1 / 2$ & Completed \\
\hline & & $\begin{array}{l}\text { Jak2 V617F positive chronic } \\
\text { myeloproliferative diseases }\end{array}$ & NCT 00606307 & 2 & Completed \\
\hline & & $\begin{array}{l}\text { Chronic myeloproliferative } \\
\text { neoplasms }\end{array}$ & NCT 01761968 & 2 & Active \\
\hline & & R/R Hodgkin's lymphoma & NCT 00496431 & $1 / 2$ & $\begin{array}{c}\text { Terminated: Well-tolerated with } \\
\text { low efficacy }\end{array}$ \\
\hline Repotrectinib * & $\begin{array}{l}\text { ROS1 inhibitor with } \\
\text { Jak2 (off target) }\end{array}$ & Solid tumors & NCT 03093116 & $1 / 2$ & Recruiting \\
\hline Zotiraciclib * & $\begin{array}{l}\text { CDK and Jak1,2 } \\
\text { inhibitor }\end{array}$ & $\begin{array}{l}\text { Adults with recurrent anaplastic } \\
\text { astrocytoma and glioblastoma }\end{array}$ & NCT 02942264 & $1 / 2$ & Recruiting \\
\hline
\end{tabular}

Current state of the clinical development of Jak1 and Jak2 inhibitors. Information in this chart has been sourced from ClinicalTrials.gov.

* Indicates documented investigation in solid tumors. Abbreviations: NK: Natural Killer, RA: Rheumatoid Arthritis, UC: Ulcerative Colitis, PC: Prostate Cancer, CRPC: Castrate-Resistant Prostate Cancer. nmPC: Non-metastatic Prostate Cancer, NSCLC: Non-small Cell Lung Carcinoma, MF: Myelofibrosis, PCV: Polycythemia Vera, ET: Essential Thrombocythemia, PSA: Prostate Specific Antigen, R/R: Refractory/Relapsed.

Table 2. JAK Family Inhibitors not in Clinical Development.

\begin{tabular}{|c|c|c|c|c|c|}
\hline Drug Name & Mechanism & Indication & NCT \# & Trial Phase & Outcome \\
\hline NVP-BSK805 & Jak2 inhibitor (Type 1) & & & 0 & \\
\hline CEP-33779 & Jak2 > Jak3 inhibitor (Type 1) & & & 0 & \\
\hline TG101209 & Jak2 inhibitor (type I) & & & 0 & \\
\hline AZ960 & Jak2 inhibitor (Type 1) & & & 0 & \\
\hline CHZ868 & Jak2 inhibitor (Type 2) & & & 0 & \\
\hline ON044580 & Jak2/BCR-ABL dual inhibitor (allosteric) & & & 0 & \\
\hline ZT55 & Jak2 inhibitor & & & 0 & \\
\hline
\end{tabular}


Table 3. Next-Generation Type I Jak2-inhibitors with terminated clinical development.

\begin{tabular}{|c|c|c|c|c|c|}
\hline Drug Name & Mechanism & Indication & NCT \# & $\begin{array}{l}\text { Trial } \\
\text { Phase }\end{array}$ & Outcome \\
\hline \multirow[t]{3}{*}{ AZD1480 } & \multirow[t]{3}{*}{$\begin{array}{l}\text { Jak1/2 inhibitor } \\
\text { (Type I) [110] }\end{array}$} & \multirow{3}{*}{$\begin{array}{l}\text { Primary myelofibrosis } \\
\text { and post-PCV /ET-MF } \\
\text { Solid tumors, gastric } \\
\text { cancer, HCC, NSCLC } \\
\text { Solid tumors }\end{array}$} & NCT 00910728 & 1 & Terminated (toxicity) \\
\hline & & & NCT 01219543 & 1 & Terminated (toxicity) \\
\hline & & & NCT 01112397 & 1 & Terminated (toxicity) \\
\hline \multirow[t]{2}{*}{ XL019 } & \multirow{2}{*}{$\begin{array}{l}\text { Jak2 inhibitor } \\
\text { (Type 1) }\end{array}$} & PCV & NCT 00595829 & 1 & Terminated (toxicity) \\
\hline & & MF & NCT 00522574 & 1 & Terminated (toxicity) \\
\hline \multirow{7}{*}{$\begin{array}{c}\text { BMS-911543 } \\
\text { MK- } \\
0457 / V X 680\end{array}$} & \multirow{7}{*}{$\begin{array}{l}\text { Jak2 inhibitor } \\
\text { Aurora kinase } \\
\text { inhibitor }\end{array}$} & MF & NCT 01236352 & $1 / 2$ & Terminated (business decision) \\
\hline & & & NCT 00111683 & 1 & Terminated (toxicity) \\
\hline & & & NCT 02532868 & 1 & Terminated (toxicity) \\
\hline & & & NCT 00290550 & $2 \mathrm{a}$ & Terminated (toxicity) \\
\hline & & & NCT 00405054 & 2 & Terminated (toxicity) \\
\hline & & & NCT 00099346 & 1 & Terminated (toxicity) \\
\hline & & & NCT 00500006 & 1 & Terminated (toxicity) \\
\hline
\end{tabular}

Information in this chart has been sourced from ClinicalTrials.gov. Abbreviations: HCC: Hepatocellular carcinoma, NSCLC: Non-small Cell Lung Carcinoma, MF: Myelofibrosis, PCV: Polycythemia Vera, ET: Essential Thrombocythemia.

\section{The First-Generation Jak1/2 Inhibitor Ruxolitinib (INCB018424/Jakafi; Incyte, Novartis)}

The first-generation pyrrolpyrimidine Jak1/2-inhibitor Ruxolitinib was the first orally available Type I inhibitor of Jak1 and Jak2 to be FDA-approved for MPDs (Table 1, Supplementary Table S1) [102,105,111-113]. Preclinical characterization showed that Ruxolitinib had IC50 values for Jak1 and Jak2 of $3.3 \mathrm{nM}$ and $2.8 \mathrm{nM}$, respectively, in a cell-free assay [111]. In the same biochemical kinase assay, the IC50 of Ruxolitinib for Jak3 was 428 $\mathrm{nM}$ [111]. Preclinical MF models indicated high efficacy of Ruxolitinib against cells and tumors expressing Jak2V617F [111]. However, no data have been reported on the potency of Ruxolitinib in any cell-based assays against the WT-Jak2 vs. mutated Jak2V617F [111,114].

Safety and early efficacy of Ruxolitinib were evaluated for MF, which indicated that the adverse effects (AEs) centered around diarrhea, fatigue and headache [112,115]. Phase II and III clinical trials (COMFORTI and COMFORT II) testing the efficacy of Ruxolitinib in MPDs indicated significantly positive responses by the reduction in splenomegaly with improved quality of life in patients with MF [116-118]. The most notable side effects of Ruxolitinib include thrombocytopenia and anemia in a dose-dependent manner [116-118]. Ruxolitinib is primarily metabolized by CYP3A4 [119,120]. Ruxolitinib is currently utilized for the therapy of PCV, with superior results compared to the current standards of therapy [121], and Ruxolitinib is also being investigated for the treatment of psoriasis, alopecia areata and lymphomas. In preclinical models, Ruxolitinib has been evaluated for efficacy in EGFR2-positive breast cancer, squamous cell carcinomas [122,123] and several other solid tumors with variable results [124,125].

Once Stat5 was identified and validated as a therapeutic target protein in PC [30,42-48], Ruxolitinib was evaluated in an interventional, off-label, single-arm study for its efficacy for treatment of metastatic CRPC (NCT 00638378). This trial was terminated due to the failure to meet the primary outcome of a detectable PSA decline in a significant number of patients. The study was intended to continue for 8 months and evaluate PSA levels monthly. Patients were administered Ruxolitinib $25 \mathrm{mg}$ twice daily in $12 \mathrm{~h}$ intervals for 21-day cycles, if well tolerated. Of the 22 patients, 16 reported treatment-related AEs, 9 of which were serious, 13 were grade 3 or 4 , and 4 patients discontinued the medication due to AEs. As the primary endpoint was not met, the secondary endpoint was not evaluated (time to progression).

The lack of efficacy of Ruxolitinib in the PC trial may have been caused by several reasons. First, it is unclear what the potency of Ruxolitinib is against cancer cells expressing WT-Jak2 vs. cells expressing the mutated Jak2V617F. While Jak2 inhibitors have predominantly been developed to target the ATP binding site in the JH1-domain of Jak2 followed 
by testing in cell-free kinase assays, only sparse data exist for most of the Jak2 inhibitors related to the evaluation of their potency in cell-based assays against WT-Jak2 vs. mutated Jak2V617F. This is relevant because it is known that CRPC cells do not express the mutated Jak2V617F [126]. If Ruxolitinib has its predominant potency against the mutated Jak2V617F, Ruxolitinib is not likely to have efficacy in PC. Second, no selection marker was utilized to identify individual PCs that would respond to Ruxolitinib favorably for accrual to the trial. An example of an effective selection marker would have been the activated Jak2-Stat5 signaling pathway in a pre-treatment biopsy. Third, the patients in this trial were not treated with ENZ or other anti-androgen prior to the accrual. Instead, the patients accrued to this study had received ADT in the form of Gonadotropin-Releasing Hormone (GnRH) agonist (such as Leuprolide or Goserelin), or they underwent a bilateral orchiectomy. Based on the recent finding of ENZ-induction of Jak2-Stat5 pathway activation in PC [24], the PCs of the patients accrued to this trial may have displayed variable activation levels of the Jak2-Stat5 signaling pathway in PC. In conclusion, it would be important to evaluate the efficacy of Ruxolitinib in ENZ-resistant PC with a selection of patients for accrual based on a positive Jak2-Stat5 activation status in PC.

\section{Next-Generation Type I Jak2-Inhibitors with FDA-Approval or in Clinical Development}

\subsection{Fedratinib (TG101348/SAR302503/Inrebic; TargeGen, Celgene, Bristol Myers Squibb)}

Dianilinopyrimidine Fedratinib is an oral, highly selective FDA-approved (in 2019) Jak2 inhibitor for intermediate/high-risk MF (Table 1, Supplementary Table S1) [127]. Cell-free kinase assays indicate an IC50 of 3 nM against both WT-Jak2 and Jak2V617F with 35-fold selectivity over Jak1 and 334-fold selectivity over Jak3 in a cell-free kinase assay [128]. While the Jak2 inhibitory activity of Fedratinib in cell-based assays has been mostly tested in models expressing Jak2V617F [127-130], robust evidence has also been presented on the potency of Fedratinib in suppressing WT-Jak2 in cell-based assays [131]. In addition, in preclinical MPD models, Fedratinib effectively inhibited proliferation of both Jak2V617F and FLT3-ITD driven cell lines with a reduction in Stat5 phosphorylation [127-130]. The safety of Fedratinib was tested in patients with primary or secondary MF in two separate trials, indicating that the main dose-limiting toxicity was an asymptomatic increase in serum amylase levels [132,133]. Other AEs included nausea, vomiting, diarrhea, anemia and thrombocythemia [132,133]. Fedratinib is metabolized by CYP3A4 [134]. Currently, Fedratinib is FDA-approved for MF based on phase II and III trials (JAKARTA), after the data indicated significant reductions of both splenomegaly and disease burden in post-Ruxolitinib setting in patients with MF $[135,136]$. Fedratinib has a black box warning for encephalopathy that occurs in approximately $1 \%$ of patients, leading to a significant delay in the overall development of the drug. Thiamine supplementation has been shown to be correlated with the elimination of encephalopathy as a severe side effect [136]. There are two phase-one clinical trials in unspecified solid tumors (NCT 01585623 and NCT 01836705).

\subsection{Pacritinib (SB1518/S-BIO; CTI-BioPharma)}

Pacritinib is a potent macrocyclic pyrimidine-based inhibitor of both Jak2 and FLT3 with minimal potency against Jak1 (Table 1, Supplementary Table S1). The IC50 of Pacritinib against Jak1, Jak2, Jak3 and Tyk2 was 1280 nM, 23 nM, 520 nM and 50 nM, respectively, in a cell-free assay [137]. Most importantly, Pacritinib has been shown to have inhibitory activity against not only Jak2V617F (IC50 19 nM) but also WT-Jak2 (IC50 23 nM) in cellbased assays [137-139]. Moreover, Pacritinib was shown to be orally available in mouse models [139] with high efficacy in suppressing Jak2-Stat5 signaling in a subcutaneous human xenograft tumor model [137]. Pacritinib successfully completed phase I and II trials in patients with myeloproliferative neoplasms (MPNs) [140-142]. The side-effects of Pacritinib included anemia, changes in hematological parameters (decreased neutrophils, lymphocytes, platelets), diarrhea (grade 1,2), fatigue and nausea [140-142]. Of note, there was minimal impact of Pacritinib on pre-existing anemia or thrombocytopenia in MPN 
patients. In fact, the majority (58\%) of patients in a phase II trial reported symptomatic improvements, and splenic size reduction was observed in 31\% of patients up to week 24 of treatment as assessed by MRI [140]. In a randomized clinical trial, Pacritinib was at least twice as effective as the best available therapy in treating MF as measured by splenic volume reduction and symptom scores [143]. The evaluation of the safety of Pacritinib and dosing in a second Phase III trial was launched by CTI-Biopharma and is currently recruiting with a goal of 105 patients with MF after prior failed Ruxolitinib therapy (NCT 03165734). Pacritinib is bound to plasma proteins at a relatively high level in humans and is metabolized by CYP3A4 but is not an inducer of CYP3A4 [144]. Pacritinib has also been investigated in patient-derived xenograft models of glioblastoma multiforme (GBM), which revealed increased survival when combined with adjuvant Temozolomide treatment [145]. Based on the evidence of the potency of Pacritinib against the WT-Jak2 in cell-based assays [137-139] and, specifically, in preclinical PC models (unpublished data), Pacritinib is currently being evaluated for safety and efficacy in a single-arm phase II trial (BLAST study) in patients with rising PSA after radical prostatectomy with PSA decline as the primary endpoint (NCT 04635059).

\subsection{Baricitinib (LY3009104/INCB028050/Olumiant; Eli Lilly)}

Baricitinib is an achiral analogue of Ruxolitinib and a potent, oral Jak1/2 inhibitor with roughly equal inhibitory effects on both kinases in a cell-free assay with IC50 values of $5.9 \mathrm{nM}, 5.7 \mathrm{nM}, 560 \mathrm{nM}$ and $53 \mathrm{nM}$ for Jak1, Jak2, Jak3 and Tyk2, respectively (Table 1) [146]. Based on testing the potency of Baricitinib in cell-free kinase assays, it has been noted that although both Jak1 and Jak2 were equally inhibited by Baricitinib, there was a 3-fold Jak1 selectivity over Jak2 [147]. No data are available on the efficacy of Baricitinib on WT-Jak2 vs. mutated Jak2V617F in cell-based assays. Currently, Baricitinib is FDA-approved (at 2 mg daily dose) for rheumatoid arthritis (RA) patients failing Tumor Necrosis Factor (TNF) inhibitors [148-150]. In addition, there are currently approximately 80 clinical trials testing the safety and efficacy of Baricitinib in other autoimmune diseases and in SARS-CoV-2patients. The primary AEs of Baricitinib include opportunistic infections, such as herpes zoster, gastro-intestinal (GI) side effects, changes in hematological parameters, malignancy and venous thromboembolism [151-153]. No studies have been conducted regarding the efficacy of Baricitinib in solid tumors.

\subsection{Momelotinib (CYT 387; Gilead)}

Momelotinib is an ATP-competitive phenylaminopyrimidine pan-Jak inhibitor with Jak1 inhibition roughly equal to Jak2 inhibition in addition to suppression of Jak3, JNK1 and CDK2 to a lesser extent (Table 1) [154]. The IC50 values of Momelotinib against Jak1, Jak2 and Jak3 were $11 \mathrm{nM}, 18 \mathrm{nM}$ and $155 \mathrm{nM}$, respectively, in a cell-free kinase assay [154]. Importantly, cell-based assays indicate the inhibitory activity of Momelotinib only against the mutated Jak2V617F [154]. In fact, no data exist on the inhibitory activity of Momelotinib against WT-Jak2 in any cell-based assays. Momelotinib has been shown to be relatively well-tolerated in two phase I/II studies with the key AEs including diarrhea, peripheral neuropathy, thrombocytopenia and dizziness $[155,156]$. Momelotinib has been shown to improve splenomegaly in MF patients in several different clinical trials [157-160]. When compared to other standards of therapy, there was a significant reduction in constitutional symptoms as well as a decreased rate of anemia. It was noted, however, that the anemia and splenomegaly improved to a lesser extent in the patients expressing WT-Jak2 compared to patients that were Jak2V617F positive. There are currently 14 clinical trials primarily investigating the use of Momelotinib in MF and PCV. Four of the clinical trials have progressed to phase III, two of which have been completed (NCT 02101268, NCT 01969838). MOMENTUM is a phase III trial in the recruiting phase, aimed to improve the outcome of anemic MF patients with previously ineffective responses to other Jak-inhibitor treatments (NCT 04173494). There are no completed clinical trials testing the efficacy of Momelotinib in solid tumors. A phase $\mathrm{Ib}$ trial investigating the efficacy of Momelotinib in non-small 
cell lung cancer (NSCLC) with adjuvant Trametinib treatment showed no benefit versus monotherapy with Trametinib [161]. Another clinical trial found no clinical benefit of Momelotinib in NSCLC but instead reported increased toxicity when given concomitantly with Erlotinib therapy [162]. Multiple other PCV and pancreatic ductal adenocarcinoma (PDAC) studies have been terminated (NCT 02101021, NCT 01998828, NCT 02244489).

\subsection{Gandotinib (LY2784544; Eli Lilly)}

Gandotinib (imidazopyridazine aminopyrazole) is an ATP-competitive Jak2 inhibitor currently intended for the therapy of Jak2V617F-positive MPNs (Table 1). Gandotinib was discovered and characterized using a Jak2-inhibition screening assay in parallel with biochemical and cell-based assays [163]. Gandotinib was shown to potently inhibit Jak2V617Fdriven signaling in Ba/F3 cells with IC50 of $20 \mathrm{nM}$, while the IC50 against IL3-stimulated WT-Jak2 in a cell-based assay was only 1183 nM [163]. Gandotinib had no effect on erythroid progenitor cells, reticulocytes or platelets in mice but was shown to significantly reduce BaF3-Jak2V617F tumor burden in the Jak2V617F-induced MPN model. A phase I safety trial indicated that the maximum-tolerated dose of Gandotinib was $120 \mathrm{mg}$ daily based on dose-limiting toxicities of blood creatinine increase or hyperuricemia at higher doses [164]. The most common treatment-emergent AEs, which were also confirmed in a phase II trial [165], were diarrhea, anemia, thrombocythemia and fatigue. The overall response rates were $95 \%, 90.5 \%$ and $9.1 \%$ for Jak2V617F positive PCV, essential thrombocythemia (ET) and MF, respectively. In Jak2V617F negative patients, overall response rates were $44 \%$ in ET and $0 \%$ in MF, supporting the notion of lesser efficacy of Gandotinib in MPNs expressing WT-Jak2 instead of the Jak2V617F [165]. Gandotinib has been tested in three completed phase I clinical trials in MPDs (NCT 01520220, NCT 01577355, NCT 01134120), with one actively recruiting phase II trial (NCT 01594723). Gandotinib has not been tested for efficacy in solid tumors.

\subsection{Peficitinib (ASP015K/Smyraf; Astellas)}

Peficitinib is an oral pan-Jak inhibitor with IC50 values in a cell-free kinase assay for Jak1, Jak2, Jak3 and Tyk2 as follows: 3.9, 5.0, 0.71 and $4.8 \mathrm{nM}$, respectively (Table 1) [166]. The primary indication of Peficitinib is currently for RA. In Japanese patients with RA and inadequate response to methotrexate (MTX), Peficitinib demonstrated superiority versus placebo in reducing RA symptoms and suppressing joint destruction (NCT 02305849). While Peficitinib was generally well tolerated, most common AEs include nasopharyngitis $(39.7 \%)$ and herpes zoster (11.7\%) in a safety study conducted in 843 patients [167]. There are currently 34 clinical trials for Peficitinib, three of which have completed phase III in Japan for patients with RA (NCT 01638013 , NCT 02308163 and NCT 02305849). Peficitinib is now fully approved in Japan for the treatment of patients with RA and failure to respond to MTX [168].

\subsection{Lestaurtinib (CEP-701; Cephalon, Teva Pharmaceuticals)}

Lestaurtinib is an oral multi-kinase inhibitor with efficacy to suppress FLT3, neurotrophin receptor Trk as well as Jak2 in a cell-free kinase assay with an IC50 of $3 \mathrm{nM}$, $<25 \mathrm{nM}$ and $0.9 \mathrm{nM}$ respectively (Table 1). Lestaurinib has been shown to inhibit phosphorylation of mutated Jak2V617F and, consequently, the phosphorylation of downstream targets such as Stat5 (IC50 10 to $30 \mathrm{nM}$ ) and Stat3 in the human erythroleukemia cell line HEL92.1.7 (homozygous for Jak2V617F mutation). Lestaurtinib was developed for treatment of various leukemias and myeloid disorders. Of the 14 documented clinical trials, one trial has progressed into phase III to investigate the potential use of Lestaurtinib as concomitant chemotherapy for acute lymphoblastic leukemia (NCT 00557193). There have been mixed results among completed clinical trials. The CEPHALON 204 trial was unable to document the efficacy of Lestaurtinib in patients with AML, likely due to the complex pharmokinetic profile of Lestaurtinib with excessive binding to plasma proteins [169]. A phase I dose-escalation study indicated similar findings, with incomplete inhibition of Stat5 
phosphorylation at lower doses of the drug in MF patients [170]. Importantly, Lestaurtinib was evaluated for efficacy in PC with PSA decline as the primary endpoint. However, the study indicated a high level of binding of Lestaurtinib to serum proteins, which limited penetration and uptake of Lestaurtinib to PC tissue (NCT 00081601). This was evaluated by administration of Lestaurtinib daily $(40 \mathrm{mg}$ ) for 5 days prior to radical prostatectomy followed by evaluation of Lestaurtinib levels in PC tissue [171]. This study illustrated that the pharmacokinetic analyses of Jak2 inhibitor levels in plasma may not reflect the levels present in solid tumor tissues.

\subsection{Tofacitinib (CP-690550/Tasocitinib/Xeljanz; Pfizer)}

Tofacitinib is a first-generation, orally bioavailable pan-Jak inhibitor. Tofacitinib was mainly developed for use as an immunosuppressant for organ transplantation and possibly for the treatment of autoimmune diseases (Table 1). Tofacitinib suppresses the Jak family members at IC50s as follows: Jak1 (112 nM), Jak2 (20 nM) and Jak3 (1 nM), in a cell-free kinase assay [172]. In addition, Tofacitinib effectively suppresses common $\gamma$-chain cytokines involving IL-2, IL-4, IL-15 and IL-21. Furthermore, Tofacitinib suppresses the signaling by IFN- $\gamma$, IL-6, and to a lesser extent IL-12 and IL-23 via Jak1 and Jak2 inhibition. Consequently, Tofacitinib influences the differentiation of CD4+ T helper cells and limits Th17 cells [173]. A study in the PC-3 PC cell line, which has a CRPC phenotype, demonstrated that Tofacitinib inhibited IL-7-dependent phosphorylation of Stat5 and IL7-induced invasion of PC cells [174]. Tofacitinib has been explored in multiple phase II and phase III clinical trials for efficacy in ulcerative colitis, RA, Down syndrome, alopecia areata, atopic dermatitis, hidradenitis suppurativa vitiligo and psoriasis. The most common side effects include headaches, upper respiratory infections, diarrhea, nasopharyngeal inflammation, elevation in low-density lipoprotein and cholesterol levels and reduction in neutrophil numbers. Serious infections including pneumonia, cellulitis and urinary tract infections have been described in patients treated with Tofacitinib. Of note, Tofacitinib is under additional monitoring for use in the EU by European Medicines Agency due to its association with blood clotting and high rate of infections. In patients in a long-term Tofacitinib clinical trial, the rate of lymphomas and other lymphoproliferative disorders was observed to be 0.07 per 100 patients over the course of each year [175]. There have been 201 clinical trials involving Tofacitinib, of which 16 are in phase IV. Interestingly, there are four clinical trials investigating the potential use of Tofacitinib in COVID-19, which are in the pre-recruiting stage (NCT 04412252, NCT 04415151, NCT 04390061 and NCT 04332042), as well as two trials for its potential therapeutic value in lymphomas and solid tumors (NCT 03598959 and NCT 04034238).

\subsection{WP1066/WP 1220 (Moleculin Biotech)}

WP1066 is a potent Jak2 inhibitor that suppresses the phosphorylation of Jak2, Stat3, Stat5, as well as ERK1and ERK2, at concentrations of 0.5, 1.0, 2.0, 3.0 and $4.0 \mu \mathrm{M}$, without affecting phosphorylation of Jak1 and Jak3 in a cell-free kinase assay (Table 1) [176]. In a cell-based assay, WP1066 inhibited the growth of erythroleukemia HEL cells carrying the mutant Jak2V617F isoform, with the IC50 values of $2.3 \mu \mathrm{M}$. Tsujita et al. showed that WP1066 suppressed Stat3 phosphorylation in bladder cancer cell lines and blocked the cell growth of those cells [177]. WP1066 is an analog of a less potent Jak2 inhibitor, AG490, which has been previously shown to inhibit the growth of various cancer cells, such as renal cell carcinoma and leukemia [178-180]. WP1066 currently has an orphan drug designation by the FDA for the treatment of brain tumors [181]. Currently, there are two documented clinical trials evaluating the efficacy of WP1066 in patients with brain tumors that are not responsive to current standards of treatment (NCT 01904123, NCT 04334863).

\subsection{Atiprimod (SKF 106615; AnorMed Inc.)}

Atiprimod is an oral small molecule belonging to the Azaspirane family. It has been shown to effectively suppress myeloma cell growth via Stat3 and Jak2 inhibition (Table 1) [182], and 
it has potential as a treatment for RA and other autoimmune diseases [183]. The inhibition of Jak2 kinase activity by Atiprimod resulted not only in antiproliferative and proapoptotic effects on Jak2V617F-expressing cell lines, such as FDCP-EpoR (murine) and SET2 (human), but also on human megakaryoblastic (CMK) cells carrying the mutation Jak3 A572V within the pseudokinase domain of Jak3. In cell-based assays, the antiproliferative activity of Atiprimod has been shown to be more potent in FDCP cells carrying mutant Jak2V617F (IC50 $0.42 \mu \mathrm{M}$ ) and SET-2 cells (IC50 $0.53 \mu \mathrm{M}$ ) than in CMK cells carrying mutant Jak3 (IC50 $0.79 \mu \mathrm{M})$ or FDCP-EpoR WT-Jak2 cells (IC50 $0.69 \mu \mathrm{M}$ ) [184]. Of note, the IC50 of Atiprimod was lower in FDCP cells carrying the Jak2V617F mutation (IC50 $0.69 \mu \mathrm{M}$ ) than CMK cells with WT-Jak2 [185]. Based on the testing of Atiprimod in cell-based assays, it was also noted that Atiprimod blocked cell growth and induced apoptosis of mantle cell lymphoma cells, while it inhibited in vivo tumor growth and increased survival of mice with mantle cell lymphoma tumors. Moreover, Atiprimod has been shown to have antiproliferative and antiangiogenic activities and induce apoptosis via activation of Caspase-3 and -8 in multiple myeloma (MM) [186]. Furthermore, Atiprimod blocked IL-6-Stat3 pathway in myeloma cells and down-regulated cell proliferation and survival by decreasing levels of the antiapoptotic proteins Bcl-2, Bcl-XL and Mcl-1 [187]. There have been two phase-II clinical trials in patients with advanced carcinoid tumors, one phase-I/IIa clinical trial in relapsed or refractory multiple myeloma sponsored by Callisto Pharmaceuticals (NCT 00388063, NCT 00663429, NCT 00086216), and one phase-I clinical trial for patients with advanced multiple myeloma who had growing tumors and symptoms that were no longer controlled by the standard therapies utilized (NCT 00430014). Interim data from this phase I trial revealed that three of the five patients treated with Atiprimod had significant clinical improvement with a decrease in debilitating symptoms and an increase in tumor regression [186]. Data from a phase I trial of oral Atiprimod in 14 patients with advanced cancers $(3+3$ design) for 14 days every 28 -day cycle demonstrated that the most common AEs were related to the gastrointestinal system. Less common AEs were sinus headaches and elevated serum transaminases, alkaline phosphatase and creatinine.

\subsection{Ilginatib (NS-018; NS Pharma)}

Ilginatib is an oral, selective Jak2 inhibitor with an IC50 of $0.72 \mathrm{nM}$ in a cell-free kinase assay (Table 1). Ilginatib induced inhibition of Stat5 phosphorylation in $\mathrm{Mac}^{+} / \mathrm{Gr} 1^{+}$ myeloid cells from bone marrow samples from Jak2V617F transgenic mice. In an MPN murine model induced by mutated Jak2V617F, hepatosplenomegaly was improved, cell invasion decreased and improved overall survival was observed [188]. An X-ray co-crystal structure revealed that the Ilginatib binds to Jak 2 in its active conformation, suggesting that hyper-activated Jak2 is potentially inhibited more effectively than WT-Jak2 [189,190]. Ilginatib is currently being tested in a clinical trial (NCT 01423851) in patients with MF, PCV and post-essential thrombocythemia myelofibrosis-(PET-MF).

\subsection{AC430/AC410 (Ambit Biosciences)}

AC430 is an oral, potent Jak2-selective inhibitor intended for autoimmune diseases and cancer with an IC50 value of $28 \mathrm{nM}$ (Table 1) [191]. In preclinical studies, AC430 exhibited potency against Jak2 and Jak2V617F mutation in cell-based models [191]. In preclinical oncology and autoimmune models, AC430 is well tolerated and has significant efficacy at oral doses as low as $10 \mathrm{mg} / \mathrm{kg} /$ day [191]. A phase I clinical trial (NCT 01287858) for AC430 on dosing and safety was completed in June 2011 and indicated no serious AEs, with the most common AEs being dysgeusia, GI-related events, fatigue and headache. Importantly, no changes in blood cell counts were observed [191]. There are currently no ongoing clinical trials listed for AC410 [191].

\subsection{LS104 (AEG 41174; Aegara Bio-Therapeutics)}

LS104 is a novel non-ATP-competitive Jak2 inhibitor developed for the treatment of leukemia and MPD (Table 1) [192]. In a cell-free kinase assay, the IC50 value of LS104 was estimated to be $1500 \mathrm{nM}$ [192]. LS104 treatment of Jak2V617F positive murine hematopoietic 
$\mathrm{Ba} / \mathrm{F} 3$ cells results in apoptosis induction in a dose-dependent manner and the inhibition of Jak2 autophosphorylation as well as the inhibition of Jak2 downstream targets [192]. Furthermore, LS104 hinders cytokine-independent growth of primary cells obtained from MPD patients with Jak2V617F mutation in an in vitro endogenous erythroid colonies assay (EEC) that focuses on the terminal erythroid differentiation. LS104 treatment in the murine model of human AML prolonged survival of mice [192]. Based on these positive findings, LS104 received investigative new drug (IND) status from the US FDA leading to a phase I clinical trial in patients with Jak2V617F-positive MPDs [192].

\subsection{Jaktinib (Suzhou Zelgen Biopharmaceuticals)}

Jaktinib is an oral and potent Jak1/2 inhibitor with an IC50 of $0.1 \mu \mathrm{M}$ based on a cellfree kinase assay (Table 1). It displays similar potency to Momelotinib and Ruxolitinib [193]. Jaktinib suppresses Jakl, Jak2, Jak3 and Tyk2 at the cellular level, inhibits the Jak-Stat signaling pathways to block the release of cytokines, including IL-2, IL-4, IL-6, IL-7 and IL-10, and significantly relieves inflammation due to immune reactions [193]. Preclinical toxicology studies conducted in Wistar rats and Beagle dogs with oral administration of Jaktinib showed no observed AEs [193]. Currently, Jaktinib is in phase II clinical trials for idiopathic pulmonary fibrosis (NCT 04312594), primary MF (NCT 04217993, NCT 03886415) and alopecia areata (NCT 04435392, NCT 04445363). A recent study indicated that Jaktinib has the potential to inhibit the proliferation of SARS-CoV-2 in vivo by inhibiting adapter associated kinase-1 (AAK1) activity, virus replication and cytokine storms to potentially delay disease progression, thereby reducing the mortality of COVID-19 [193].

\subsection{AT9283 (Astex Pharmaceuticals)}

AT9283 is a multikinase inhibitor with IC50 in cell-free assays against Aurora Kinase A/B of approximately $3 \mathrm{nM}$, and the IC50 for Jak2 and Jak3 were $1.2 \mathrm{nM}$ and $1.1 \mathrm{nM}$, respectively (Table 1, Supplementary Table S1) [179]. Qi et al. demonstrated that AT9283 induced apoptosis and inhibited cell proliferation in B-Non-Hodgkin lymphoma (B-NHL) cell lines at an IC50 $<1 \mu \mathrm{M}$ in a dose- and time-dependent manner. The same study showed that AT9283 in combination with Docetaxel induced significant apoptosis at a very low dose $(5 \mathrm{nM})$ compared to a single treatment of the B-NHL cells with either of the compounds. In vivo mouse xenograft tumors of mantle cell lymphoma treated with AT9283 (15 or $20 \mathrm{mg} / \mathrm{kg}$ ) plus Docetaxel $(10 \mathrm{mg} / \mathrm{kg}$ ) showed a significant decrease in tumor growth and enhanced survival of the mice [180]. Similarly, a study in multiple myeloma (MM) demonstrated that a combination of AT9283 with Lenalidomide (orally active immunomodulator) led to significant synergistic cytotoxicity in preclinical models, and the proposed mechanism of action was blocking Stat3 phosphorylation [194]. AT9283 has been tested in five clinical trials, two of which have investigated the potential therapeutic value of AT9283 in solid tumors (NCT 00443976, NCT 00985868). A phase I trial in pediatric patients with solid tumors (unspecified relapsed and refractory solid tumors) revealed that AT9283 was well-tolerated with manageable hematological AEs. The overall notable AEs were GI-side effects (75\%), including nausea, diarrhea, constipation, stomatitis and vomiting (19\%). Other AEs included pneumonia, fatigue, febrile neutropenia, peripheral edema, headache and epistaxis [195]. AT9283 has been developed by Astex, and it has progressed to a completed phase II trial investigating its potential use in multiple myeloma (NCT 01145989). However, the trial results indicated that AT9283 at a dose of $40 \mathrm{mg} / \mathrm{m}^{2}$ and on a schedule (days 1 and 8 of a 21-day cycle) was not suggested for further studies as a treatment for myeloma [195].

\subsection{Cerdulatinib (PRT062070; Portola Pharmaceuticals)}

Cerdulatinib is an orally active, small-molecule inhibitor with activity against 24 kinases with an IC50 range below $200 \mathrm{nM}$ (Table 1, Supplementary Table S1). In a cell-free kinase assay, the IC50 values for Jak1, Jak2, Jak3 and Tyk2 were $12 \mathrm{nM}, 6 \mathrm{nM}, 8 \mathrm{nM}$ and $0.5 \mathrm{nM}$, respectively. Further studies showed that Cerdulatinib induced significant apop- 
tosis in NHL-cell lines expressing B-cell antigen receptor (BCR)-signaling. Furthermore, Cerdulatinib significantly inhibited the viability of $\mathrm{CD} 19^{+}$cells isolated from 60 primary chronic lymphocytic leukemia (CLL) patient samples at clinically attainable concentrations. In those 60 primary CLL samples, the IC50 of Cerdulatinib ranged from 0.4 to $10.0 \mu \mathrm{M}$ with cell viability as the endpoint, and the average IC50 for the cohort was $2.6 \mu \mathrm{M}$ and the median IC50 was $1.5 \mu \mathrm{M}$. According to a clinical pharmacokinetic study, these concentrations are clinically achievable [196]. Additionally, Ibrutinib-resistant primary CLL cell growth was inhibited by Cerdulatinib, and these anti-tumor effects were proposed to be linked to inhibition of BCR, IL-4/Jak1/Jak3/Stat6 and IL-6/Jak1/Jak2/Stat3 signaling [196]. Cerdulatinib has progressed into a phase IIb clinical trial studying relapsed/refractory peripheral T-cell lymphoma (PTCL) (NCT 04021082), a phase IIa clinical trial to assess the safety and tolerability for patients with vitiligo (NCT 04103060); and a phase I/IIa dose-escalation study in CLL, small lymphocytic lymphoma (SLL) or B-cell non-Hodgkin lymphoma (NHL) (NCT 01994382). A next clinical trial (NCT 04757259) is currently available for eligible patients with relapsed/refractory CLL or NHL for patients who experienced clinical benefit from Cerdulatinib (NCT 01994382).

\subsection{Filgotinib (GLPG0634/GS-6034/Jyseleca; Galapagos NV)}

Filgotinib is a selective Jak inhibitor that demonstrates potent activity for Jak1 over Jak2, Jak3 and Tyk2 with IC50 values of $10 \mathrm{nM}, 28 \mathrm{nM}, 810 \mathrm{nM}$ and $116 \mathrm{nM}$, respectively (Table 1, Supplementary Table S1) [147]. Further, cell-based assays revealed that Filgotinib and its active metabolites block Jak1-dependent cytokine signaling pathways [197]. In a preclinical setting, Filgotinib inhibited Stat3 and the expression of the oncostatin-M receptor (OSMR) in oncogene-driven NSCLC [198]. Filgotinib is currently being developed for the treatment of RA, psoriatic arthritis, ankylosing spondylitis and inflammatory bowel disease. Filgotinib has progressed into several phase II and phase III studies, mostly investigating its potential in RA [199]. Filgotinib received its first approval in the EU [200] and Japan [201] in 2020 for the treatment of moderate to severe active RA in adults. However, pre-clinical animal studies showed that Filgotinib impaired spermatogenesis. Therefore, US FDA has requested data from two ongoing studies, the MANTA (NCT 03201445) and MANTA-Ray (NCT 03926195), to assess whether Filgotinib has an impact on sperm parameters in adult males [202]. Among 448 patients treated with Filgotinib, 1\% developed herpes zoster retinal vein occlusion. Common side effects noted so far include nasopharyngitis (10.2\%) and headache and nasopharyngitis (5.9\% each) [203].

\subsection{Decernotinib (VX 509; Vertex Pharmaceuticals)}

Decernotinib is an oral selective Jak3 inhibitor developed for the treatment of RA (Table 1, Supplementary Table S1) [204]. Animal pharmacology studies in a rat collageninduced arthritis model (CIA) demonstrated that inflammation was significantly reduced in a dose-dependent manner. Many of the physiological mechanisms associated with RA, such as bone resorption and cartilage damage, were also reduced [204]. Decernotinib was evaluated in six phase-II clinical trials (NCT 01830985, NCT 01886209, NCT 01754935, NCT 01590459, NCT 00789126, NCT 01052194). Decernotinib has been shown to be well tolerated except for increased opportunistic infections, elevation in the levels of transaminase and creatinine, as well as lipoproteins in blood [205]. Vertex has discontinued the clinical development of Decernotinib for RA [205].

\subsection{Erlotinib (Tarceva; Genentech)}

Erlotinib is an oral EGFR (tyrosine kinase) inhibitor with potent off-target Jak2 inhibitory effects (Table 1, Supplementary Table S1). Erlotinib was initially developed for therapy in patients with NSCLC, as it has been documented to inhibit the growth of Jak2V617F positive hematopoietic progenitor cells and human erythroleukemia (HEL cells). In a study investigating the potency of Erlotinib in PCV in a cell-based assay, WT-Jak2 was inhibited with an IC50 of $>20 \mu \mathrm{M}$ and Jak2V617F at $4 \mu \mathrm{M}$ [206]. Of particular interest, 
Erlotinib has been investigated clinically in PC with an emphasis on EGFR as a primary target. Overall, in a phase II study of 30 patients with PC (29 with CRPC, 23 of which had been treated with prior chemotherapy), a clinical benefit was shown in $40 \%$ of patients with an endpoint of a decrease in PSA without clinical progression. Another similar study enrolled 29 patients and showed that there was a moderate clinical improvement in chemotherapy naïve CRPC defined by a decrease in PSA levels [207]. There are 589 clinical trials for Erlotinib investigating its use in many various cancers, 74 of which pertain to solid tumors, 8 for PC. Erlotinib has been FDA approved for over a decade in NSCLC and is produced by Genentech. Most common AEs related to Erlotinib included cutaneous changes such as rash and hair loss, as well as other neurogenic inflammation [208].

\subsection{Givinostat (ITF2357; ItalFarmaco)}

Givinostat is primarily an oral, histone-deacetylase (HDAC) inhibitor as well as a potent inhibitor of hematopoietic colony formation by Jak2V617F-expressing progenitor cells from chronic MPN in vitro (Table 1, Supplementary Table S1). Givinostat was well tolerated in MF patients in a phase II trial. Side effects observed were GI-related and fatigue [209]. Givinostat treatment resulted in neoplastic inhibition in MF and MPNs. Proliferation was inhibited and apoptosis was induced in vitro in B-cell acute lymphoblastic leukemia (BCP-ALL) cytokine receptor-like factor 2 (CRLF2) cell lines without the induction of death of normal hematopoietic cells. Givinostat has been reported to downregulate Jak-Stat pathways leading to a significant decrease in Stat5 phosphorylation. In vivo, Givinostat significantly reduced engraftment of human blasts in patient-derived xenograft models of CRLF2-positive BCP-ALL cells. Additionally, Givinostat killed Ruxolitinibresistant cells and potentiated the effect of current chemotherapy [210]. Givinostat is being tested in 17 ongoing clinical trials, mainly in patients with PCV, muscular dystrophy, MPNs, lymphomas or arthritis. Three phase-II clinical trials have been completed for Givinostat: Two for PCV (NCT 01901432, NCT 00928707) and one for Duchenne muscular dystrophy (DMD) (NCT 01761292). One phase-II clinical trial for polyarticular course juvenile idiopathic arthritis (NCT 01261624) has been terminated.

\subsection{Repotrectinib (TPX0005; Turning Point Therapeutics)}

Repotrectinib is a potent inhibitor of Ros1, Trk and Alk (Table 1, Supplementary Table S1). Other clinically relevant kinases inhibited by Repotrectinib are Jak2, Lyn, Src and Fak. The IC50 in a cell-free assay of Repotrectinib against Ros1, TrkA, TrkB, TrkC, Alk, Jak2, Lyn, Src and Fak were $0.07 \mathrm{nM}, 0.83 \mathrm{nM}, 0.05 \mathrm{nM}, 0.1 \mathrm{nM}, 1.01 \mathrm{nM}, 1.04 \mathrm{nM}, 1.66 \mathrm{nM}, 5.3$ $\mathrm{nM}$ and $6.96 \mathrm{nM}$, respectively [211,212]. The off-target effects of Repotrectinib on Jak2 may potentially provide a longer duration of action and inhibit the development of resistance mechanisms in NSCLC. Repotrectinib inhibited proliferation of Ba/F3 cells in vitro, and tumor volumes were decreased in mice expressing Ba/F3 Cd74-Ros1-WT or Cd74-Ros1G2032R xenograft tumors. In addition, Repotrectinib inhibited Stat5 phosphorylation with IC50 of $158 \mathrm{nM}$ in SET2 cells and Src phosphorylation with IC50 of $89 \mathrm{nM}$ in H2228 cells [213]. There have been three clinical trials for Repotrectinib: One in phase I for NSCLC (NCT 04772235) and two clinical trials in phase II for pediatric patients harboring Alk, Ros1 or Ntrk1-3 mutations in solid tumors, lymphomas and central nervous system tumors (NCT 04094610), and adult patients with advanced solid malignancies harboring an Alk, Ros1, Ntrk1, Ntrk2 or Ntrk3 gene rearrangement (NCT 03093116). In the currently available data, Repotrectinib was generally well tolerated by oral administration in patients.

\subsection{Zotiraciclib (TG02; Adastra Pharmaceuticals)}

Zotiraciclib is a pyrimidine-based multi-kinase inhibitor that inhibits CDK 1, CDK2, CDK7 and CDK9 as well as Jak2 and FLT3 (Table 1, Supplementary Table S1) [214]. The primary molecular targets of Zotiraciclib are CDK proteins, but Zotiraciclib has also been shown to inhibit Jak2 and FLT3 in cancer cells [214]. Zotiraciclib has high potency against CDKs with an IC50 of 3-9 nM, and the IC50s for Jak1/Jak2/Tyk2 were between 14 and 
$59 \mathrm{nM}$ in cell-free assays [215]. In cell-based assays, the growth of patient-derived acute myeloid leukemia (AML) and PCV primary cell lines was effectively inhibited [214]. Studies utilizing AML xenograft models in vivo confirmed the in vitro findings, wherein Zotiraciclib induced effective blockade of Stat3, Stat5 and CDK signaling leading to tumor regression and prolonged survival of mice carrying the tumors [214]. Preclinical studies in glioblastoma cells demonstrated that Zotiraciclib decreased cellular ATP production by suppressing glycolysis, leading to mitochondrial dysfunction resulting in glioblastoma cell death. In December 2019, the FDA granted orphan drug status to Zotiraciclib for use in patients with glioblastoma [214]. This designation was based on the results from the NCI-sponsored phase I/II trial at the NIH Clinical Center (NCT 02942264) [214].

\section{Next-Generation Type I Jak2-Inhibitors Currently in Pre-Clinical Development 4.1. NVP-BSK805 (Novartis)}

NVP-BSK805 is an ATP-competitive Jak2 inhibitor with IC50s of $0.5 \mathrm{nM}, 32 \mathrm{nM}, 19 \mathrm{nM}$ and $11 \mathrm{nM}$ in a cell-free assay for Jak2, Jak1, Jak3 and Tyk2, respectively (Table 2) [216]. NVP-BSK805 suppressed growth, induced apoptosis and inhibited constitutive Stat5 phosphorylation at IC50 $<100 \mathrm{nM}$ in cells expressing mutated Jak2V617F [216]. In contrast, greater than $1 \mu \mathrm{M}$ concentrations of NVP-BSK805 were required to inhibit growth and Stat5 phosphorylation in K562 cells carrying a BCR-ABL fusion [216]. In a Ba/F3 Jak2V617F cell-driven mouse model, NVP-BSK805 was efficacious in suppressing Stat5 phosphorylation, leukemic cell spreading and splenomegaly at $150 \mathrm{mg} / \mathrm{kg}$ by oral administration. Additionally, NVP-BSK805 suppressed recombinant human erythropoietin-induced polycythemia and extramedullary erythropoiesis in mice and rats at doses of 25,50 and $100 \mathrm{mg} / \mathrm{kg}$ by oral administration [216]. There are no clinical trials listed for NVP-BSK805 at this time.

\subsection{CEP-33779 (Cephalon Inc./Teva Pharmaceuticals)}

CEP-33779 is a highly selective, orally bioavailable Jak2 inhibitor (Table 2). The IC50 of Jak2 is $1.8 \mathrm{nM}$, and for other Jak family members, CEP-33779 demonstrated varying levels of selectivity from $>40$-fold versus Jak1 to $>800$-fold against Tyk2 in a cell-free assay. In two RA mouse models, Jak2 inhibition by CEP-33779 decreased the mean paw edema and clinical scores [217]. Another in vivo study demonstrated that CEP-33779 treatment $(10 \mathrm{mg} / \mathrm{kg}, 30 \mathrm{mg} / \mathrm{kg}$ and $55 \mathrm{mg} / \mathrm{kg}$ ) resulted in significant inhibition of established colorectal tumors by decreasing angiogenesis and proliferation of tumor cells. Furthermore, the reduced tumor burden was linked to decreased Stat3 and NF-KB (RelA/p65) activation [218]. Although preclinical results have been promising, there are currently no listed clinical trials.

\subsection{TG101209 (TargeGen/Sanofi)}

TG101209 is a selective small-molecule inhibitor of Jak2, which potently inhibits mutations associated with MPDs (Table 2). TG101209 inhibits Jak2, FLT3 and RET kinases at IC50 values of $6 \mathrm{nM}, 25 \mathrm{nM}$ and $17 \mathrm{nM}$, respectively. However, TG101209 showed substantially less activity against other tyrosine kinases, including Jak3 IC50 of $169 \mathrm{nM}$ [219]. In vitro studies showed that Ba/F3 cell growth (Jak2V617F) was inhibited at IC50 of $200 \mathrm{nM}$. Furthermore, TG101209 directly induced cell cycle arrest, apoptosis and blocked the phosphorylation of Jak2V617F, Stat5 and Stat3 in myeloid leukemia cells [219]. In vivo studies demonstrated that SCID mice injected intravenously with Ba/F3 cells expressing Jak2V617F exhibited a significant decrease in Stat5 phosphorylation in splenic tumors after the administration of two oral doses of TG101209 (50 mg/kg) [220]. Another study showed that in lung cancer cell lines HCC2429 and H460, TG101209 inhibited STAT3 activation and surviving expression and sensitized the cells to radiation in clonogenic assays. Furthermore, the addition of TG101209 to radiation delayed the growth of lung cancer xenograft tumors by increasing apoptosis and decreasing cell proliferation [221]. Moreover, T-cell-ALL treated with TG101209 significantly inhibited T-ALL cell proliferation and induced cell 
apoptosis in a dose-dependent manner [222]. Even though these preclinical data with TG101209 have been highly promising, there are no current clinical trials.

\subsection{AZ960 (AstraZeneca)}

AZ960 is a highly potent ATP competitive Jak2 inhibitor with IC50 values against Jak2 and Jak3 of $3 \mathrm{nM}$ and $9 \mathrm{nM}$, respectively, in a cell-free assay (Table 2) [223]. In addition, AZ960 has been shown to have inhibitory activity against other kinases, including Trk-A, Aurora-A and Fak, with IC50 of $100 \mathrm{nM}$ [224]. In cell-based assays, AZD960 inhibited Jak2 and Stat 5 phosphorylation and down-regulated proliferation of Ba/F3 cells expressing TELJak2 (catalytic domain of Jak2 fused with the oligomerization domain of the TEL protein, resulting in constitutive activation of the Jak2 kinase activity) [224]. In addition, AZD960 demonstrated selectivity for TEL-Jak2-driven Stat5 phosphorylation and cell proliferation when compared with cell lines driven by similar fusions of the other Jak kinases (Jak1, Jak3 and Tyk2) [224]. Moreover, AZD960 suppressed constitutive and inducible Stat3 activation and as well as the growth of xenograft tumors of breast, ovarian and PC origin in mice, suggesting that Jak2 is required for Stat 3 activation in solid tumors [225]. Moreover, AZD960 suppressed constitutive and inducible Stat3 activation and as well as the growth of xenograft tumors of breast, ovarian and PC origin in mice, suggesting that Jak2 is required for Stat3 activation in solid tumors [223]. There are no clinical trials testing the safety or efficacy of AZ960 in any tumor type.

\subsection{CHZ868 (Novartis)}

Novartis launched a discovery program to identify type II Jak2 inhibitors with improved potency, selectivity and physicochemical properties, which led to the discovery of CHZ868 (Table 2) [226]. CHZ868 is a Type II Jak2 inhibitor that stabilizes Jak2 in an inactive conformation and prevents Jak2 autophosphorylation [227]. In a comparison between Jak2V617F expressing SET-2 cells and mutant Jak3A572V expressing acute myeloblastic leukemia (MKB) cells, CHZ868 was highly selective for Jak2 over other Jak family members [227]. In vivo, CHZ868 demonstrated favorable efficacy in reducing growth in the Jak2V617F knock-in mouse model of PCV and, similarly, in MF mouse models [227]. A key finding related to CHZ868 was that withdrawal of CHZ868 did not trigger Stat rebound signaling as has been observed for Type I Jak2 inhibitors [227]. The same study showed that CHZ868 potently suppressed the growth of MHH-CALL4 leukemia cells with IC50 values in the range of $100 \mathrm{nM}$, while $1 \mu \mathrm{M}$ of CHZ868 suppressed Jak2 phosphorylation, suggesting the involvement of other signaling pathways than Jak2 in the growth regulation of these cells [227]. There are no clinical trials ongoing for CHZ868 due to toxicity in preclinical models.

\subsection{ON044580 (Onconova Therapeutics)}

ON044580 is a non-ATP mimetic (Type I) Jak2 and BCR-ABL kinases inhibitor (Table 2). Studies in vitro, using a recombinant Jak2 protein, showed that ON044580 inhibited the kinase activity of recombinant Jak2 with an IC50 between 0.9 and $1.2 \mu \mathrm{M}$ in a cell-free assay [228]. ON044580 was also able to inhibit the activated Jak2V617F mutant with an IC50 between 0.8-1.1 $\mu \mathrm{M}$ [228]. In the same assay, it was shown that the JH2 domain is necessary for ON044580 to effectively inhibit Jak2 [228]. In cell-based assays, the suppression of Jak2 and Stat5 phosphorylation was documented within $30 \mathrm{~min}$ of compound administration to Jak2V617Fpositive leukemia cells. This caused both growth arrest and apoptosis within human and mouse leukemia cells positive for Jak2V617F [228]. Patient-derived CML cells that were refractory to Imatinib (BCR-ABL kinase inhibitor) displayed high sensitivity to ON044580. In BCR-ABL+ cells, ON044580 induced apoptosis led to a rapid decrease in BCR-ABL protein levels [229]. Consequently, targeting Jak2 and BCR-ABL kinases with ON044580 has the potential to manage multiple types of drug-resistant CML cells where tyrosine kinase inhibitors are not clinically useful. There are no clinical trials reported at this time [229]. 


\subsection{ZT55 (Molnova)}

ZT55 is a highly selective Jak2 inhibitor with IC50 of $0.031 \mu \mathrm{M}$ against Jak2 in a cell-free kinase assay (Table 2) [230]. ZT55 exhibits potent effects on the Jak-Stat pathway, downstream Stat $3 / 5$ transcription factors and inhibits tyrosine phosphorylation in Jak2V617F mutation on HEL cell line [230]. In addition, ZT55 effectively inhibited proliferation of HEL cell line expressing Jak2V617F mutation, followed by cell cycle arrest at G2/M phase leading to caspase-dependent apoptosis [230]. The growth of HEL xenograft tumors in vivo was significantly suppressed by ZT55 treatment [230]. Further evaluation indicated inhibition of erythroid colony formation of peripheral blood hematopoietic progenitor cells from patients carrying the Jak2V617F mutation by ZT55 [230]. No current clinical trials have been listed.

\section{Next-Generation Type I Jak2-Inhibitors with the Clinical Development Terminated 5.1. AZD1480 (AstraZeneca)}

AZD1480 is a potent, ATP mimetic inhibitor of Jak2 with an IC50 of less than $0.4 \mathrm{nM}$ in a cell-free assay (Table 3 ). In cell-based assays and in various xenograft tumor models, AZD1480 demonstrated inhibition of Stat3 and Stat5 [231]. In particular, AZD1480 potently inhibited both Stat 5 and Stat 3 in preclinical models of PC, resulting in reduced PC cell viability and CRPC tumor growth after androgen deprivation conducted by surgical castration $[47,84,232]$. Higher concentrations of AZD1480 have been shown to suppress Aurora A/B Kinase and histone $\mathrm{H} 3$ phosphorylation [233]. In addition, the proliferation of myeloma cells was potently inhibited in vitro and in vivo secondary to the inhibition of phosphorylated FGFR3, phosphorylation of Jak2 and Stat3 and Cyclin D2 by AZD1480 [233]. AZD1480 was tested in three clinical trials investigating its potential safety and efficacy in treating solid tumors (NCT 01219543, NCT 01112397) and MF/PCV (NCT 00910728). The preliminary results led to early termination due to reversible neurotoxicity [233].

\subsection{XL019 (Exelixis Inc.)}

XL019 is a potent, orally active and selective Jak2 inhibitor, with IC50 of $2.2 \mathrm{nM}$, $134.3 \mathrm{nM}$ and $214.2 \mathrm{nM}$ for Jak2, Jak1 and Jak3, respectively, based on a cell-free kinase assay (Table 3) [234]. XL019 inhibits Stat3 and Stat5 phosphorylation in cells expressing either Jak2V617F or WT-Jak2 [234]. In addition, XL109 demonstrated efficacy in AML xenograft tumor mouse models [235]. XL019 was evaluated in two phase-I clinical trials in patients with PCV or MF (NCT 00595829 and NCT 00522574), which were both terminated due to safety concerns related to neurotoxicity in the patient [235].

\subsection{BMS-911543 (Bristol-Myers Squibb)}

BMS-911543 is a highly selective small-molecule inhibitor of Jak2 with 74-fold selectivity over Jak3 and 350-fold selectively over Jak1 (Table 3). In a cell-free assay, the IC50 values of BMS-911543 for Jak1, Jak2, Jak3 and Tyk2 were $356 \mathrm{nM}, 1.1 \mathrm{nM}, 73 \mathrm{nM}$ and $66 \mathrm{nM}$, respectively [236]. BMS-911543 has been shown to induce anti-proliferative responses in SET-2 and BaF3 cell lines, both engineered to express Jak2V617F, compared to non-Jak2-dependent cell lines (A549, MDA-MB-231, MiaPaCa-2) [237]. Furthermore, BMS-911543 blocked the growth of primary progenitor cells isolated from patients with Jak2V617F-positive MPNs in a colony formation assay [238]. BMS-911543 has been tested in one clinical trial (NCT 01236352), which was terminated.

\subsection{Tozasertib (MK-0457/VX680; Vertex Pharmaceuticals/Merck)}

Tozasertib is the first potent Aurora kinase inhibitor that has been tested in clinical trials (Table 3). Preclinical studies demonstrated that Tozasertib inhibited both Aurora kinase A and B activity [239-241]. Other kinases that have been described as molecular targets of Tozasertib are FLT-3 and ABL and Jak2 kinase [239]. Upon treatment with Tozasertib, inhibition of cell growth and increased apoptosis have been reported in PC and thyroid, ovarian and oral squamous cancer cell lines [240-242]. Tozasertib also reduces 
tumor growth in an in vivo model of PC [241]. Tozasertib has been evaluated in seven clinical trials for efficacy in hematological malignancies, advanced solid tumors, colorectal cancer and NSCLC. Although the preliminary clinical results were promising, the clinical development has been terminated with only one completed trial in patients with leukemia (NCT 00111683) with concerns for neutropenia, thrombocytopenia and anemia [239,241].

\section{Conclusions}

Most of the Jak2 inhibitors show high efficacy against WT-Jak2 in cell-free assays but lack evidence for efficacy against WT-Jak2 in cell-based assays. In other words, the cell-based assays that have been utilized to test the efficacy/potency of Jak2 inhibitors are cell/tumor models expressing mutated Jak2V617F. In this regard, it is important to note that the mutated Jak2V617F is not expressed in clinical PC. The Jak2 inhibitors with higher potency or exclusive potency against mutated Jak2V617F compared to WT-Jak2 are not likely to have significant efficacy against PC growth. The third key point is that most Jak2-inhibitors in preclinical and clinical development do have simultaneous inhibitory activity against Jak1. However, since Stat3 is pro-oncogenic in PC cells, the simultaneous inhibition of Jak1/Jak2-Stat3 axis is actually beneficial for the desired outcome of blocking PC growth and potential metastatic progression.

In terms of AEs, most of the next-generation Jak2 inhibitors are relatively well tolerated with the AEs, mainly including GI effects, fatigue, opportunistic infections and anemia. The clinical development of many of the first-generation Jak2 inhibitors has been discontinued because of neurotoxicity. Overall, there is substantial evidence to support chemotherapeutic use of Jak2/Stat5 inhibitors for CRPC from both preclinical and clinical studies. Many of the next-generation Type I Jak2 inhibitors are well tolerated with oral bioavailability. In summary, evaluation in phase I/II clinical trials is warranted to determine the potential efficacy of the next-generation Type I Jak2 inhibitors that have demonstrated efficacy in cell-based assays against WT-Jak2 in PC.

In summary, the key challenges related to the first-generation Jak2 inhibitors included neurotoxicity due to the ability of those compounds to cross the blood-brain barrier. This was followed by the development of a set of next-generation Type I Jak2 inhibitors with decreased neurotoxicity and improved safety profiles. However, many of the nextgeneration Jak1/2 inhibitors in the clinical development are associated with increased infection rates and yet unknown effects on the host immune system and, for example, the gut microbiota that warrant additional studies. Both Fedratinib and Pacritinib are furthest along as Type I next-generation Jak2 inhibitors for oral administration in the clinical development and with largely manageable AE profiles.

Supplementary Materials: The following are available online at https:/ / www.mdpi.com/article/10.339 0/cancers13205204/s1, Table S1: Chemical structures of JAK Family Inhibitors in Clinical Development.

Author Contributions: Investigation, Data Curation and Writing-Original Draft Preparation, P.B., L.S., V.U., C.M., S.M.D. and M.T.N.; Writing-Review and Editing, P.S.L., K.M.J., S.T., K.A.I., L.W., W.A.H., D.K. and M.T.N.; Supervision, M.T.N. and D.K. All authors have read and agreed to the published version of the manuscript.

Funding: This work was partially supported by Advancing a Healthier Wisconsin (\#5520368) and Wisconsin Cancer Showhouse Grant (\#15437) to MTN and a grant from National Institute of Health and the National Cancer Institute (NCI) (1R01CA212097) to LW and MTN, a grant from NCI (R01CA249882) to PSL, a grant National Center for Advancing Translational Sciences, National Institutes of Health (KL2TR001438) to WAH and a grant from AHW (5520566) to PB and MTN.

Conflicts of Interest: The authors declare no conflict of interest. 


\section{References}

1. American Cancer Society. Cancer Facts \& Figures 2019. Available online: https://www.cancer.org/research/cancer-factsstatistics/all-cancer-facts-figures/cancer-facts-figures-2019.html (accessed on 10 April 2021).

2. Labrie, F.; Belanger, A.; Simard, J.; Labrie, C.; Dupont, A. Combination therapy for prostate cancer. Endocrine and biologic basis of its choice as new standard first-line therapy. Cancer 1993, 71, 1059-1067. [CrossRef]

3. Yap, T.A.; Zivi, A.; Omlin, A.; de Bono, J.S. The changing therapeutic landscape of castration-resistant prostate cancer. Nat. Rev. Clin. Oncol. 2011, 8, 597-610. [CrossRef]

4. Wong, Y.N.; Ferraldeschi, R.; Attard, G.; de Bono, J. Evolution of androgen receptor targeted therapy for advanced prostate cancer. Nat. Rev. Clin. Oncol. 2014, 11, 365-376. [CrossRef]

5. Attard, G.; Parker, C.; Eeles, R.A.; Schroder, F.; Tomlins, S.A.; Tannock, I.; Drake, C.G.; de Bono, J.S. Prostate cancer. Lancet 2016, 387, 70-82. [CrossRef]

6. Litwin, M.S.; Tan, H.J. The Diagnosis and Treatment of Prostate Cancer: A Review. JAMA 2017, 317, 2532-2542. [CrossRef] [PubMed]

7. Masiello, D.; Cheng, S.; Bubley, G.J.; Lu, M.L.; Balk, S.P. Bicalutamide functions as an androgen receptor antagonist by assembly of a transcriptionally inactive receptor. J. Biol. Chem. 2002, 277, 26321-26326. [CrossRef] [PubMed]

8. Beer, T.M.; Armstrong, A.J.; Rathkopf, D.E.; Loriot, Y.; Sternberg, C.N.; Higano, C.S.; Iversen, P.; Bhattacharya, S.; Carles, J.; Chowdhury, S.; et al. Enzalutamide in metastatic prostate cancer before chemotherapy. N. Engl. J. Med. 2014, 371, 424-433. [CrossRef] [PubMed]

9. Ning, Y.M.; Pierce, W.; Maher, V.E.; Karuri, S.; Tang, S.H.; Chiu, H.J.; Palmby, T.; Zirkelbach, J.F.; Marathe, D.; Mehrotra, N.; et al. Enzalutamide for treatment of patients with metastatic castration-resistant prostate cancer who have previously received docetaxel: U.S. Food and Drug Administration drug approval summary. Clin. Cancer Res. 2013, 19, 6067-6073. [CrossRef]

10. Beer, T.M.; Armstrong, A.J.; Rathkopf, D.; Loriot, Y.; Sternberg, C.N.; Higano, C.S.; Iversen, P.; Evans, C.P.; Kim, C.S.; Kimura, G.; et al. Enzalutamide in Men with Chemotherapy-naive Metastatic Castration-resistant Prostate Cancer: Extended Analysis of the Phase 3 PREVAIL Study. Eur. Urol. 2017, 71, 151-154. [CrossRef]

11. Ning, Y.M.; Brave, M.; Maher, V.E.; Zhang, L.; Tang, S.; Sridhara, R.; Kim, G.; Ibrahim, A.; Pazdur, R.U.S. Food and Drug Administration Approval Summary: Enzalutamide for the Treatment of Patients With Chemotherapy-Naive Metastatic CastrationResistant Prostate Cancer. Oncologist 2015, 20, 960-966. [CrossRef]

12. Tran, C.; Ouk, S.; Clegg, N.J.; Chen, Y.; Watson, P.A.; Arora, V.; Wongvipat, J.; Smith-Jones, P.M.; Yoo, D.; Kwon, A.; et al. Development of a second-generation antiandrogen for treatment of advanced prostate cancer. Science 2009, 324, 787-790. [CrossRef]

13. Chong, J.T.; Oh, W.K.; Liaw, B.C. Profile of apalutamide in the treatment of metastatic castration-resistant prostate cancer: Evidence to date. Onco Targets Ther. 2018, 11, 2141-2147. [CrossRef]

14. Saad, F.; Hotte, S.J. Guidelines for the management of castrate-resistant prostate cancer. Can. Urol. Assoc. J. 2010, 4, 380-384. [CrossRef]

15. Claessens, F.; Helsen, C.; Prekovic, S.; Van den Broeck, T.; Spans, L.; Van Poppel, H.; Joniau, S. Emerging mechanisms of enzalutamide resistance in prostate cancer. Nat. Rev. Urol. 2014, 11, 712-716. [CrossRef] [PubMed]

16. Watson, P.A.; Arora, V.K.; Sawyers, C.L. Emerging mechanisms of resistance to androgen receptor inhibitors in prostate cancer. Nat. Rev. Cancer 2015, 15, 701-711. [CrossRef] [PubMed]

17. Antonarakis, E.S.; Lu, C.; Wang, H.; Luber, B.; Nakazawa, M.; Roeser, J.C.; Chen, Y.; Mohammad, T.A.; Chen, Y.; Fedor, H.L.; et al. AR-V7 and resistance to enzalutamide and abiraterone in prostate cancer. N. Engl. J. Med. 2014, 371, 1028-1038. [CrossRef] [PubMed]

18. Dehm, S.M.; Schmidt, L.J.; Heemers, H.V.; Vessella, R.L.; Tindall, D.J. Splicing of a novel androgen receptor exon generates a constitutively active androgen receptor that mediates prostate cancer therapy resistance. Cancer Res. 2008, 68, 5469-5477. [CrossRef]

19. Arora, V.K.; Schenkein, E.; Murali, R.; Subudhi, S.K.; Wongvipat, J.; Balbas, M.D.; Shah, N.; Cai, L.; Efstathiou, E.; Logothetis, C.; et al. Glucocorticoid receptor confers resistance to antiandrogens by bypassing androgen receptor blockade. Cell 2013, 155, 1309-1322. [CrossRef]

20. Joseph, J.D.; Lu, N.; Qian, J.; Sensintaffar, J.; Shao, G.; Brigham, D.; Moon, M.; Maneval, E.C.; Chen, I.; Darimont, B.; et al. A clinically relevant androgen receptor mutation confers resistance to second-generation antiandrogens enzalutamide and ARN-509. Cancer Discov. 2013, 3, 1020-1029. [CrossRef]

21. Korpal, M.; Korn, J.M.; Gao, X.; Rakiec, D.P.; Ruddy, D.A.; Doshi, S.; Yuan, J.; Kovats, S.G.; Kim, S.; Cooke, V.G.; et al. An F876L mutation in androgen receptor confers genetic and phenotypic resistance to MDV3100 (enzalutamide). Cancer Discov. 2013, 3, 1030-1043. [CrossRef]

22. Beltran, H.; Prandi, D.; Mosquera, J.M.; Benelli, M.; Puca, L.; Cyrta, J.; Marotz, C.; Giannopoulou, E.; Chakravarthi, B.V.; Varambally, S.; et al. Divergent clonal evolution of castration-resistant neuroendocrine prostate cancer. Nat. Med. 2016, 22, 298-305. [CrossRef]

23. Bluemn, E.G.; Coleman, I.M.; Lucas, J.M.; Coleman, R.T.; Hernandez-Lopez, S.; Tharakan, R.; Bianchi-Frias, D.; Dumpit, R.F.; Kaipainen, A.; Corella, A.N.; et al. Androgen Receptor Pathway-Independent Prostate Cancer Is Sustained through FGF Signaling. Cancer Cell 2017, 32, 474e476-489e476. [CrossRef] 
24. Udhane, V.; Maranto, C.; Hoang, D.T.; Gu, L.; Erickson, A.; Devi, S.; Talati, P.G.; Banerjee, A.; Iczkowski, K.A.; Jacobsohn, K.; et al. Enzalutamide-Induced Feed-Forward Signaling Loop Promotes Therapy-Resistant Prostate Cancer Growth Providing an Exploitable Molecular Target for Jak2 Inhibitors. Mol. Cancer Ther. 2020, 19, 231-246. [CrossRef]

25. Ghoreschi, K.; Laurence, A.; O'Shea, J.J. Janus kinases in immune cell signaling. Immunol. Rev. 2009, 228, 273-287. [CrossRef] [PubMed]

26. Silvennoinen, O.; Hubbard, S.R. Molecular insights into regulation of JAK2 in myeloproliferative neoplasms. Blood 2015, 125, 3388-3392. [CrossRef] [PubMed]

27. Rui, H.; Djeu, J.Y.; Evans, G.A.; Kelly, P.A.; Farrar, W.L. Prolactin receptor triggering. Evidence for rapid tyrosine kinase activation. J. Biol. Chem. 1992, 267, 24076-24081. [CrossRef]

28. Rui, H.; Lebrun, J.J.; Kirken, R.A.; Kelly, P.A.; Farrar, W.L. JAK2 activation and cell proliferation induced by antibody-mediated prolactin receptor dimerization. Endocrinology 1994, 135, 1299-1306. [CrossRef]

29. Dagvadorj, A.; Collins, S.; Jomain, J.B.; Abdulghani, J.; Karras, J.; Zellweger, T.; Li, H.; Nurmi, M.; Alanen, K.; Mirtti, T.; et al. Autocrine prolactin promotes prostate cancer cell growth via Janus kinase-2-signal transducer and activator of transcription-5a/b signaling pathway. Endocrinology 2007, 148, 3089-3101. [CrossRef]

30. Talati, P.G.; Gu, L.; Ellsworth, E.M.; Girondo, M.A.; Trerotola, M.; Hoang, D.T.; Leiby, B.; Dagvadorj, A.; McCue, P.A.; Lallas, C.D.; et al. Jak2-Stat5a/b Signaling Induces Epithelial-to-Mesenchymal Transition and Stem-Like Cell Properties in Prostate Cancer. Am. J. Pathol. 2015, 185, 2505-2522. [CrossRef]

31. Li, H.; Ahonen, T.J.; Alanen, K.; Xie, J.; LeBaron, M.J.; Pretlow, T.G.; Ealley, E.L.; Zhang, Y.; Nurmi, M.; Singh, B.; et al. Activation of signal transducer and activator of transcription 5 in human prostate cancer is associated with high histological grade. Cancer Res. 2004, 64, 4774-4782. [CrossRef]

32. Levy, D.E.; Darnell, J.E., Jr. Stats: Transcriptional control and biological impact. Nat. Rev. Mol. Cell Biol. $2002,3,651-662$. [CrossRef]

33. Quintas-Cardama, A.; Verstovsek, S. Molecular pathways: Jak/STAT pathway: Mutations, inhibitors, and resistance. Clin. Cancer Res. 2013, 19, 1933-1940. [CrossRef]

34. Ihle, J.N. The Stat family in cytokine signaling. Curr. Opin. Cell Biol. 2001, 13, 211-217. [CrossRef]

35. Liu, X.; Robinson, G.W.; Gouilleux, F.; Groner, B.; Hennighausen, L. Cloning and expression of Stat5 and an additional homologue (Stat5b) involved in prolactin signal transduction in mouse mammary tissue. Proc. Natl. Acad. Sci. USA 1995, 92, 8831-8835. [CrossRef]

36. Liu, X.; Robinson, G.W.; Hennighausen, L. Activation of Stat5a and Stat5b by tyrosine phosphorylation is tightly linked to mammary gland differentiation. Mol. Endocrinol. 1996, 10, 1496-1506. [CrossRef] [PubMed]

37. Heinrich, P.C.; Behrmann, I.; Haan, S.; Hermanns, H.M.; Muller-Newen, G.; Schaper, F. Principles of interleukin (IL)-6-type cytokine signalling and its regulation. Biochem. J. 2003, 374, 1-20. [CrossRef] [PubMed]

38. Jones, S.A.; Scheller, J.; Rose-John, S. Therapeutic strategies for the clinical blockade of IL-6/gp130 signaling. J. Clin. Investig. 2011, 121, 3375-3383. [CrossRef] [PubMed]

39. Pestell, R.G.; Nevalainen, M.T. Prostate Cancer: Signaling Networks, Genetics, and New Treatment Strategies; Humana Press: Totowa, NJ, USA, 2008.

40. Yamasaki, K.; Taga, T.; Hirata, Y.; Yawata, H.; Kawanishi, Y.; Seed, B.; Taniguchi, T.; Hirano, T.; Kishimoto, T. Cloning and expression of the human interleukin-6 (BSF-2/IFN beta 2) receptor. Science 1988, 241, 825-828. [CrossRef] [PubMed]

41. Wen, Z.; Zhong, Z.; Darnell, J.E., Jr. Maximal activation of transcription by Stat1 and Stat3 requires both tyrosine and serine phosphorylation. Cell 1995, 82, 241-250. [CrossRef]

42. Ahonen, T.J.; Xie, J.; LeBaron, M.J.; Zhu, J.; Nurmi, M.; Alanen, K.; Rui, H.; Nevalainen, M.T. Inhibition of transcription factor Stat5 induces cell death of human prostate cancer cells. J. Biol. Chem. 2003, 278, 27287-27292. [CrossRef]

43. Dagvadorj, A.; Kirken, R.A.; Leiby, B.; Karras, J.; Nevalainen, M.T. Transcription factor signal transducer and activator of transcription 5 promotes growth of human prostate cancer cells in vivo. Clin. Cancer Res. 2008, 14, 1317-1324. [CrossRef]

44. Gu, L.; Dagvadorj, A.; Lutz, J.; Leiby, B.; Bonuccelli, G.; Lisanti, M.P.; Addya, S.; Fortina, P.; Dasgupta, A.; Hyslop, T.; et al Transcription factor Stat3 stimulates metastatic behavior of human prostate cancer cells in vivo, whereas Stat $5 \mathrm{~b}$ has a preferential role in the promotion of prostate cancer cell viability and tumor growth. Am. J. Pathol. 2010, 176, 1959-1972. [CrossRef] [PubMed]

45. Gu, L.; Vogiatzi, P.; Puhr, M.; Dagvadorj, A.; Lutz, J.; Ryder, A.; Addya, S.; Fortina, P.; Cooper, C.; Leiby, B.; et al. Stat5 promotes metastatic behavior of human prostate cancer cells in vitro and in vivo. Endocr. Relat. Cancer 2010, 17, 481-493. [CrossRef] [PubMed]

46. Liao, Z.; Gu, L.; Vergalli, J.; Mariani, S.A.; De Dominici, M.; Lokareddy, R.K.; Dagvadorj, A.; Purushottamachar, P.; McCue, P.A.; Trabulsi, E.; et al. Structure-Based Screen Identifies a Potent Small Molecule Inhibitor of Stat5a/b with Therapeutic Potential for Prostate Cancer and Chronic Myeloid Leukemia. Mol. Cancer Ther. 2015, 14, 1777-1793. [CrossRef] [PubMed]

47. Gu, L.; Liao, Z.; Hoang, D.T.; Dagvadorj, A.; Gupta, S.; Blackmon, S.; Ellsworth, E.; Talati, P.; Leiby, B.; Zinda, M.; et al. Pharmacologic inhibition of Jak2-Stat5 signaling By Jak2 inhibitor AZD1480 potently suppresses growth of both primary and castrate-resistant prostate cancer. Clin. Cancer Res. 2013, 19, 5658-5674. [CrossRef]

48. Kazansky, A.V.; Spencer, D.M.; Greenberg, N.M. Activation of signal transducer and activator of transcription 5 is required for progression of autochthonous prostate cancer: Evidence from the transgenic adenocarcinoma of the mouse prostate system. Cancer Res. 2003, 63, 8757-8762. 
49. Hoang, D.T.; Iczkowski, K.A.; Kilari, D.; See, W.; Nevalainen, M.T. Androgen receptor-dependent and-independent mechanisms driving prostate cancer progression: Opportunities for therapeutic targeting from multiple angles. Oncotarget 2017, 8, $3724-3745$. [CrossRef]

50. Thomas, C.; Zoubeidi, A.; Kuruma, H.; Fazli, L.; Lamoureux, F.; Beraldi, E.; Monia, B.P.; MacLeod, A.R.; Thuroff, J.W.; Gleave, M.E. Transcription factor Stat5 knockdown enhances androgen receptor degradation and delays castration-resistant prostate cancer progression in vivo. Mol. Cancer Ther. 2011, 10, 347-359. [CrossRef]

51. Maranto, C.; Udhane, V.; Jia, J.; Verma, R.; Muller-Newen, G.; LaViolette, P.S.; Pereckas, M.; Sabharwal, L.; Terhune, S.; Pattabiraman, N.; et al. Prospects for Clinical Development of Stat5 Inhibitor IST5-002: High Transcriptomic Specificity in Prostate Cancer and Low Toxicity In Vivo. Cancers 2020, 12, 3412. [CrossRef]

52. Haddad, B.R.; Gu, L.; Mirtti, T.; Dagvadorj, A.; Vogiatzi, P.; Hoang, D.T.; Bajaj, R.; Leiby, B.; Ellsworth, E.; Blackmon, S.; et al. STAT5A/B gene locus undergoes amplification during human prostate cancer progression. Am. J. Pathol. 2013, 182, $2264-2275$. [CrossRef]

53. Li, H.; Zhang, Y.; Glass, A.; Zellweger, T.; Gehan, E.; Bubendorf, L.; Gelmann, E.P.; Nevalainen, M.T. Activation of signal transducer and activator of transcription-5 in prostate cancer predicts early recurrence. Clin. Cancer Res. 2005, 11, 5863-5868. [CrossRef] [PubMed]

54. Mirtti, T.; Leiby, B.E.; Abdulghani, J.; Aaltonen, E.; Pavela, M.; Mamtani, A.; Alanen, K.; Egevad, L.; Granfors, T.; Josefsson, A.; et al. Nuclear Stat $5 \mathrm{a} / \mathrm{b}$ predicts early recurrence and prostate cancer-specific death in patients treated by radical prostatectomy. Hum. Pathol. 2013, 44, 310-319. [CrossRef]

55. Haddad, B.R.; Erickson, A.; Udhane, V.; LaViolette, P.S.; Rone, J.D.; Kallajoki, M.A.; See, W.A.; Rannikko, A.; Mirtti, T.; Nevalainen, M.T. Positive STAT5 Protein and Locus Amplification Status Predicts Recurrence after Radical Prostatectomy to Assist Clinical Precision Management of Prostate Cancer. Cancer Epidemiol. Biomark. Prev. 2019, 28, 1642-1651. [CrossRef] [PubMed]

56. Nakonechnaya, A.O.; Jefferson, H.S.; Chen, X.; Shewchuk, B.M. Differential effects of exogenous and autocrine growth hormone on LNCaP prostate cancer cell proliferation and survival. J. Cell Biochem. 2013, 114, 1322-1335. [CrossRef] [PubMed]

57. Nakonechnaya, A.O.; Shewchuk, B.M. Growth hormone enhances LNCaP prostate cancer cell motility. Endocr. Res. 2015, 40, 97-105. [CrossRef]

58. Zhang, Y.; Gc, S.; Patel, S.B.; Liu, Y.; Paterson, A.J.; Kappes, J.C.; Jiang, J.; Frank, S.J. Growth hormone (GH) receptor (GHR)-specific inhibition of GH-Induced signaling by soluble IGF-1 receptor (sol IGF-1R). Mol. Cell Endocrinol. 2019, 492, 110445. [CrossRef]

59. Goffin, V. Prolactin receptor targeting in breast and prostate cancers: New insights into an old challenge. Pharmacol. Ther. 2017, 179, 111-126. [CrossRef]

60. Rouet, V.; Bogorad, R.L.; Kayser, C.; Kessal, K.; Genestie, C.; Bardier, A.; Grattan, D.R.; Kelder, B.; Kopchick, J.J.; Kelly, P.A.; et al. Local prolactin is a target to prevent expansion of basal/stem cells in prostate tumors. Proc. Natl. Acad. Sci. USA 2010, 107, 15199-15204. [CrossRef]

61. Sackmann-Sala, L.; Goffin, V. Prolactin-induced prostate tumorigenesis. Adv. Exp. Med. Biol. 2015, 846, 221-242. [CrossRef]

62. Gan, Y.; Zhang, Y.; Buckels, A.; Paterson, A.J.; Jiang, J.; Clemens, T.L.; Zhang, Z.Y.; Du, K.; Chang, Y.; Frank, S.J. IGF-1R modulation of acute GH-induced STAT5 signaling: Role of protein tyrosine phosphatase activity. Mol. Endocrinol. 2013, 27, 1969-1979. [CrossRef]

63. Jeong, J.Y.; Hoxhaj, G.; Socha, A.L.; Sytkowski, A.J.; Feldman, L. An erythropoietin autocrine/paracrine axis modulates the growth and survival of human prostate cancer cells. Mol. Cancer Res. 2009, 7, 1150-1157. [CrossRef] [PubMed]

64. Amorino, G.P.; Deeble, P.D.; Parsons, S.J. Neurotensin stimulates mitogenesis of prostate cancer cells through a novel c-Src/Stat5b pathway. Oncogene 2007, 26, 745-756. [CrossRef] [PubMed]

65. Feldman, L.; Wang, Y.; Rhim, J.S.; Bhattacharya, N.; Loda, M.; Sytkowski, A.J. Erythropoietin stimulates growth and STAT5 phosphorylation in human prostate epithelial and prostate cancer cells. Prostate 2006, 66, 135-145. [CrossRef] [PubMed]

66. Ahonen, T.J.; Harkonen, P.L.; Rui, H.; Nevalainen, M.T. PRL signal transduction in the epithelial compartment of rat prostate maintained as long-term organ cultures in vitro. Endocrinology 2002, 143, 228-238. [CrossRef] [PubMed]

67. Ahonen, T.J.; Harkonen, P.L.; Laine, J.; Rui, H.; Martikainen, P.M.; Nevalainen, M.T. Prolactin is a survival factor for androgendeprived rat dorsal and lateral prostate epithelium in organ culture. Endocrinology 1999, 140, 5412-5421. [CrossRef] [PubMed]

68. Nevalainen, M.T.; Valve, E.M.; Ahonen, T.; Yagi, A.; Paranko, J.; Harkonen, P.L. Androgen-dependent expression of prolactin in rat prostate epithelium in vivo and in organ culture. FASEB J. 1997, 11, 1297-1307. [CrossRef]

69. Nevalainen, M.T.; Valve, E.M.; Ingleton, P.M.; Harkonen, P.L. Expression and hormone regulation of prolactin receptors in rat dorsal and lateral prostate. Endocrinology 1996, 137, 3078-3088. [CrossRef]

70. Nevalainen, M.T.; Valve, E.M.; Ingleton, P.M.; Nurmi, M.; Martikainen, P.M.; Harkonen, P.L. Prolactin and prolactin receptors are expressed and functioning in human prostate. J. Clin. Investig. 1997, 99, 618-627. [CrossRef]

71. Nevalainen, M.T.; Valve, E.M.; Makela, S.I.; Blauer, M.; Tuohimaa, P.J.; Harkonen, P.L. Estrogen and prolactin regulation of rat dorsal and lateral prostate in organ culture. Endocrinology 1991, 129, 612-622. [CrossRef]

72. Mora, L.B.; Buettner, R.; Seigne, J.; Diaz, J.; Ahmad, N.; Garcia, R.; Bowman, T.; Falcone, R.; Fairclough, R.; Cantor, A.; et al. Constitutive activation of Stat3 in human prostate tumors and cell lines: Direct inhibition of Stat 3 signaling induces apoptosis of prostate cancer cells. Cancer Res. 2002, 62, 6659-6666.

73. Campbell, C.L.; Jiang, Z.; Savarese, D.M.; Savarese, T.M. Increased expression of the interleukin-11 receptor and evidence of STAT3 activation in prostate carcinoma. Am. J. Pathol. 2001, 158, 25-32. [CrossRef] 
74. Huang, H.F.; Murphy, T.F.; Shu, P.; Barton, A.B.; Barton, B.E. Stable expression of constitutively-activated STAT3 in benign prostatic epithelial cells changes their phenotype to that resembling malignant cells. Mol. Cancer 2005, 4, 2. [CrossRef]

75. Dhir, R.; Ni, Z.; Lou, W.; DeMiguel, F.; Grandis, J.R.; Gao, A.C. Stat3 activation in prostatic carcinomas. Prostate 2002, 51, $241-246$. [CrossRef] [PubMed]

76. Horinaga, M.; Okita, H.; Nakashima, J.; Kanao, K.; Sakamoto, M.; Murai, M. Clinical and pathologic significance of activation of signal transducer and activator of transcription 3 in prostate cancer. Urology 2005, 66, 671-675. [CrossRef] [PubMed]

77. Chen, T.; Wang, L.H.; Farrar, W.L. Interleukin 6 activates androgen receptor-mediated gene expression through a signal transducer and activator of transcription 3-dependent pathway in LNCaP prostate cancer cells. Cancer Res. 2000, 60, 2132-2135. [PubMed]

78. Matsuda, T.; Junicho, A.; Yamamoto, T.; Kishi, H.; Korkmaz, K.; Saatcioglu, F.; Fuse, H.; Muraguchi, A. Cross-talk between signal transducer and activator of transcription 3 and androgen receptor signaling in prostate carcinoma cells. Biochem. Biophys. Res. Commun. 2001, 283, 179-187. [CrossRef]

79. Ueda, T.; Bruchovsky, N.; Sadar, M.D. Activation of the androgen receptor N-terminal domain by interleukin-6 via MAPK and STAT3 signal transduction pathways. J. Biol. Chem. 2002, 277, 7076-7085. [CrossRef]

80. Yang, L.; Wang, L.; Lin, H.K.; Kan, P.Y.; Xie, S.; Tsai, M.Y.; Wang, P.H.; Chen, Y.T.; Chang, C. Interleukin-6 differentially regulates androgen receptor transactivation via PI3K-Akt, STAT3, and MAPK, three distinct signal pathways in prostate cancer cells. Biochem. Biophys. Res. Commun. 2003, 305, 462-469. [CrossRef]

81. Barton, B.E.; Karras, J.G.; Murphy, T.F.; Barton, A.; Huang, H.F. Signal transducer and activator of transcription 3 (STAT3) activation in prostate cancer: Direct STAT3 inhibition induces apoptosis in prostate cancer lines. Mol. Cancer Ther. 2004, 3, 11-20.

82. DeMiguel, F.; Lee, S.O.; Lou, W.; Xiao, X.; Pflug, B.R.; Nelson, J.B.; Gao, A.C. Stat3 enhances the growth of LNCaP human prostate cancer cells in intact and castrated male nude mice. Prostate 2002, 52, 123-129. [CrossRef]

83. Lou, W.; Ni, Z.; Dyer, K.; Tweardy, D.J.; Gao, A.C. Interleukin-6 induces prostate cancer cell growth accompanied by activation of stat3 signaling pathway. Prostate 2000, 42, 239-242. [CrossRef]

84. Gu, L.; Talati, P.; Vogiatzi, P.; Romero-Weaver, A.L.; Abdulghani, J.; Liao, Z.; Leiby, B.; Hoang, D.T.; Mirtti, T.; Alanen, K.; et al. Pharmacologic suppression of JAK1/2 by JAK1/2 inhibitor AZD1480 potently inhibits IL-6-induced experimental prostate cancer metastases formation. Mol. Cancer Ther. 2014, 13, 1246-1258. [CrossRef]

85. Abdulghani, J.; Gu, L.; Dagvadorj, A.; Lutz, J.; Leiby, B.; Bonuccelli, G.; Lisanti, M.P.; Zellweger, T.; Alanen, K.; Mirtti, T.; et al. Stat3 promotes metastatic progression of prostate cancer. Am. J. Pathol. 2008, 172, 1717-1728. [CrossRef]

86. Culig, Z.P.R.; Nevalainen, M.T. Transcription factors Stat5 and Stat3: Survival Factors for Prostate Cancer Cells. In Prostate Cancer: Signaling Networks, Genetics and New Treatment Strategies; Nevalainen, P., Ed.; Springer: Totowa, NJ, USA, 2008 ; pp. $257-455$.

87. Hobisch, A.; Rogatsch, H.; Hittmair, A.; Fuchs, D.; Bartsch, G., Jr.; Klocker, H.; Bartsch, G.; Culig, Z. Immunohistochemical localization of interleukin-6 and its receptor in benign, premalignant and malignant prostate tissue. J. Pathol. 2000, 191, 239-244. [CrossRef]

88. Royuela, M.; Ricote, M.; Parsons, M.S.; Garcia-Tunon, I.; Paniagua, R.; de Miguel, M.P. Immunohistochemical analysis of the IL-6 family of cytokines and their receptors in benign, hyperplastic, and malignant human prostate. J. Pathol. 2004, 202, 41-49. [CrossRef]

89. Drachenberg, D.E.; Elgamal, A.A.; Rowbotham, R.; Peterson, M.; Murphy, G.P. Circulating levels of interleukin-6 in patients with hormone refractory prostate cancer. Prostate 1999, 41, 127-133. [CrossRef]

90. George, D.J.; Halabi, S.; Shepard, T.F.; Sanford, B.; Vogelzang, N.J.; Small, E.J.; Kantoff, P.W. The prognostic significance of plasma interleukin-6 levels in patients with metastatic hormone-refractory prostate cancer: Results from cancer and leukemia group B 9480. Clin. Cancer Res. 2005, 11, 1815-1820. [CrossRef]

91. Michalaki, V.; Syrigos, K.; Charles, P.; Waxman, J. Serum levels of IL-6 and TNF-alpha correlate with clinicopathological features and patient survival in patients with prostate cancer. Br. J. Cancer 2004, 90, 2312-2316. [CrossRef] [PubMed]

92. Nakashima, J.; Tachibana, M.; Horiguchi, Y.; Oya, M.; Ohigashi, T.; Asakura, H.; Murai, M. Serum interleukin 6 as a prognostic factor in patients with prostate cancer. Clin. Cancer Res. 2000, 6, 2702-2706. [PubMed]

93. Shariat, S.F.; Andrews, B.; Kattan, M.W.; Kim, J.; Wheeler, T.M.; Slawin, K.M. Plasma levels of interleukin-6 and its soluble receptor are associated with prostate cancer progression and metastasis. Urology 2001, 58, 1008-1015. [CrossRef]

94. Twillie, D.A.; Eisenberger, M.A.; Carducci, M.A.; Hseih, W.S.; Kim, W.Y.; Simons, J.W. Interleukin-6: A candidate mediator of human prostate cancer morbidity. Urology 1995, 45, 542-549. [CrossRef]

95. Wise, G.J.; Marella, V.K.; Talluri, G.; Shirazian, D. Cytokine variations in patients with hormone treated prostate cancer. J. Urol. 2000, 164, 722-725. [CrossRef]

96. Hobisch, A.; Ramoner, R.; Fuchs, D.; Godoy-Tundidor, S.; Bartsch, G.; Klocker, H.; Culig, Z. Prostate cancer cells (LNCaP) generated after long-term interleukin-6 treatment express interleukin-6 and acquire an interleukin-6-partially resistant phenotype. Clin. Cancer Res. 2001, 7, 2941-2948. [PubMed]

97. Levine, R.L.; Loriaux, M.; Huntly, B.J.; Loh, M.L.; Beran, M.; Stoffregen, E.; Berger, R.; Clark, J.J.; Willis, S.G.; Nguyen, K.T.; et al. The JAK2V617F activating mutation occurs in chronic myelomonocytic leukemia and acute myeloid leukemia, but not in acute lymphoblastic leukemia or chronic lymphocytic leukemia. Blood 2005, 106, 3377-3379. [CrossRef]

98. Levine, R.L.; Wadleigh, M.; Cools, J.; Ebert, B.L.; Wernig, G.; Huntly, B.J.; Boggon, T.J.; Wlodarska, I.; Clark, J.J.; Moore, S.; et al. Activating mutation in the tyrosine kinase JAK2 in polycythemia vera, essential thrombocythemia, and myeloid metaplasia with myelofibrosis. Cancer Cell 2005, 7, 387-397. [CrossRef] 
99. Kralovics, R.; Passamonti, F.; Buser, A.S.; Teo, S.S.; Tiedt, R.; Passweg, J.R.; Tichelli, A.; Cazzola, M.; Skoda, R.C. A gain-of-function mutation of JAK2 in myeloproliferative disorders. N. Engl. J. Med. 2005, 352, 1779-1790. [CrossRef] [PubMed]

100. Baxter, E.J.; Scott, L.M.; Campbell, P.J.; East, C.; Fourouclas, N.; Swanton, S.; Vassiliou, G.S.; Bench, A.J.; Boyd, E.M.; Curtin, N.; et al. Acquired mutation of the tyrosine kinase JAK2 in human myeloproliferative disorders. Lancet 2005, 365, $1054-1061$. [CrossRef]

101. James, C.; Ugo, V.; Le Couedic, J.P.; Staerk, J.; Delhommeau, F.; Lacout, C.; Garcon, L.; Raslova, H.; Berger, R.; Bennaceur-Griscelli, A.; et al. A unique clonal JAK2 mutation leading to constitutive signalling causes polycythaemia vera. Nature 2005, 434, 1144-1148. [CrossRef]

102. Meyer, S.C.; Levine, R.L. Molecular pathways: Molecular basis for sensitivity and resistance to JAK kinase inhibitors. Clin Cancer Res. 2014, 20, 2051-2059. [CrossRef]

103. Meyer, S.C.; Keller, M.D.; Chiu, S.; Koppikar, P.; Guryanova, O.A.; Rapaport, F.; Xu, K.; Manova, K.; Pankov, D.; O’Reilly, R.J.; et al. CHZ868, a Type II JAK2 Inhibitor, Reverses Type I JAK Inhibitor Persistence and Demonstrates Efficacy in Myeloproliferative Neoplasms. Cancer Cell 2015, 28, 15-28. [CrossRef]

104. Plimack, E.R.; Lorusso, P.M.; McCoon, P.; Tang, W.; Krebs, A.D.; Curt, G.; Eckhardt, S.G. AZD1480: A phase I study of a novel JAK2 inhibitor in solid tumors. Oncologist 2013, 18, 819-820. [CrossRef]

105. Mascarenhas, J.; Hoffman, R. Ruxolitinib: The first FDA approved therapy for the treatment of myelofibrosis. Clin. Cancer Res. 2012, 18, 3008-3014. [CrossRef] [PubMed]

106. Kesarwani, M.; Huber, E.; Kincaid, Z.; Evelyn, C.R.; Biesiada, J.; Rance, M.; Thapa, M.B.; Shah, N.P.; Meller, J.; Zheng, Y.; et al. Targeting substrate-site in Jak2 kinase prevents emergence of genetic resistance. Sci. Rep. 2015, 5, 14538. [CrossRef]

107. Singer, J.W.; Al-Fayoumi, S.; Ma, H.; Komrokji, R.S.; Mesa, R.; Verstovsek, S. Comprehensive kinase profile of pacritinib, a nonmyelosuppressive Janus kinase 2 inhibitor. J. Exp. Pharmacol. 2016, 8, 11-19. [CrossRef] [PubMed]

108. Monaghan, K.A.; Khong, T.; Burns, C.J.; Spencer, A. The novel JAK inhibitor CYT387 suppresses multiple signalling pathways, prevents proliferation and induces apoptosis in phenotypically diverse myeloma cells. Leukemia 2011, 25, 1891-1899. [CrossRef] [PubMed]

109. Hodge, J.; Kawabata, T.; Krishnaswami, S.; Clark, J.; Telliez, J.-B.; Dowty, M.; Menon, S.; Lamba, M.; Zwillich, S. The mechanism of action of tofacitinib-An oral Janus kinase inhibitor for the treatment of rheumatoid arthritis. Clin. Exp. Rheumatol. 2016, 34, 318-328.

110. Vainchenker, W.; Leroy, E.; Gilles, L.; Marty, C.; Plo, I.; Constantinescu, S.N. JAK inhibitors for the treatment of myeloproliferative neoplasms and other disorders. F1000Res 2018, 7, 82. [CrossRef] [PubMed]

111. Quintas-Cardama, A.; Vaddi, K.; Liu, P.; Manshouri, T.; Li, J.; Scherle, P.A.; Caulder, E.; Wen, X.; Li, Y.; Waeltz, P.; et al. Preclinical characterization of the selective JAK1/2 inhibitor INCB018424: Therapeutic implications for the treatment of myeloproliferative neoplasms. Blood 2010, 115, 3109-3117. [CrossRef]

112. Verstovsek, S.; Kantarjian, H.; Mesa, R.A.; Pardanani, A.D.; Cortes-Franco, J.; Thomas, D.A.; Estrov, Z.; Fridman, J.S.; Bradley, E.C.; Erickson-Viitanen, S.; et al. Safety and efficacy of INCB018424, a JAK1 and JAK2 inhibitor, in myelofibrosis. N. Engl. J. Med. 2010, 363, 1117-1127. [CrossRef]

113. Moran, N. Incyte comes of age with JAK inhibitor approval. Nat. Biotechnol. 2012, 30, 3-5. [CrossRef]

114. Deshpande, A.; Reddy, M.M.; Schade, G.O.; Ray, A.; Chowdary, T.K.; Griffin, J.D.; Sattler, M. Kinase domain mutations confer resistance to novel inhibitors targeting JAK2V617F in myeloproliferative neoplasms. Leukemia 2012, 26, 708-715. [CrossRef]

115. Shi, J.G.; Chen, X.; Lee, F.; Emm, T.; Scherle, P.A.; Lo, Y.; Punwani, N.; Williams, W.V.; Yeleswaram, S. The pharmacokinetics, pharmacodynamics, and safety of baricitinib, an oral JAK $1 / 2$ inhibitor, in healthy volunteers. J. Clin. Pharmacol. 2014, 54, 1354-1361. [CrossRef] [PubMed]

116. Harrison, C.; Kiladjian, J.J.; Al-Ali, H.K.; Gisslinger, H.; Waltzman, R.; Stalbovskaya, V.; McQuitty, M.; Hunter, D.S.; Levy, R.; Knoops, L.; et al. JAK inhibition with ruxolitinib versus best available therapy for myelofibrosis. N. Engl. J. Med. 2012, 366, 787-798. [CrossRef] [PubMed]

117. Harrison, C.N.; Vannucchi, A.M.; Kiladjian, J.J.; Al-Ali, H.K.; Gisslinger, H.; Knoops, L.; Cervantes, F.; Jones, M.M.; Sun, K.; McQuitty, M.; et al. Long-term findings from COMFORT-II, a phase 3 study of ruxolitinib vs best available therapy for myelofibrosis. Leukemia 2017, 31, 775. [CrossRef]

118. Verstovsek, S.; Vannucchi, A.M.; Griesshammer, M.; Masszi, T.; Durrant, S.; Passamonti, F.; Harrison, C.N.; Pane, F.; Zachee, P.; Kirito, K.; et al. Ruxolitinib versus best available therapy in patients with polycythemia vera: 80 -week follow-up from the RESPONSE trial. Haematologica 2016, 101, 821-829. [CrossRef] [PubMed]

119. Shi, J.G.; Chen, X.; Emm, T.; Scherle, P.A.; McGee, R.F.; Lo, Y.; Landman, R.R.; McKeever, E.G., Jr.; Punwani, N.G.; Williams, W.V.; et al. The effect of CYP3A4 inhibition or induction on the pharmacokinetics and pharmacodynamics of orally administered ruxolitinib (INCB018424 phosphate) in healthy volunteers. J. Clin. Pharmacol. 2012, 52, 809-818. [CrossRef] [PubMed]

120. Shilling, A.D.; Nedza, F.M.; Emm, T.; Diamond, S.; McKeever, E.; Punwani, N.; Williams, W.; Arvanitis, A.; Galya, L.G.; Li, M.; et al. Metabolism, excretion, and pharmacokinetics of [14C]INCB018424, a selective Janus tyrosine kinase 1/2 inhibitor, in humans. Drug Metab. Dispos. 2010, 38, 2023-2031. [CrossRef] [PubMed]

121. Vannucchi, A.M. Ruxolitinib versus standard therapy for the treatment of polycythemia vera. N. Engl. J. Med. 2015, 372, 1670-1671. [CrossRef] [PubMed] 
122. Vallath, S.; Sage, E.K.; Kolluri, K.K.; Lourenco, S.N.; Teixeira, V.S.; Chimalapati, S.; George, P.J.; Janes, S.M.; Giangreco, A. CADM1 inhibits squamous cell carcinoma progression by reducing STAT3 activity. Sci. Rep. 2016, 6, 24006. [CrossRef]

123. Yang, P.W.; Huang, P.M.; Yong, L.S.; Chang, Y.H.; Wu, C.W.; Hua, K.T.; Hsieh, M.S.; Lee, J.M. Circulating Interleukin-6 is Associated with Prognosis and Genetic Polymorphisms of MIR608 in Patients with Esophageal Squamous Cell Carcinoma. Ann. Surg. Oncol. 2018, 25, 2449-2456. [CrossRef]

124. Ojha, R.S.S.; Bhattacharyya, S. JAK-mediated autophagy regulates stemness and cell survival in cisplatin resistant bladder cancer cells. Biochim. Biophys. Acta 2016, 1860, 2484-2497. [CrossRef] [PubMed]

125. Morgan, E.L.; Macdonald, A. JAK2 Inhibition Impairs Proliferation and Sensitises Cervical Cancer Cells to Cisplatin-Induced Cell Death. Cancers 2019, 11, 1934. [CrossRef] [PubMed]

126. Gu, L.; Zhu, X.H.; Visakorpi, T.; Alanen, K.; Mirtti, T.; Edmonston, T.B.; Nevalainen, M.T. Activating mutation (V617F) in the tyrosine kinase JAK2 is absent in locally-confined or castration-resistant prostate cancer. Anal. Cell Pathol. 2010, 33, 55-59. [CrossRef]

127. Talpaz, M.; Kiladjian, J.J. Fedratinib, a newly approved treatment for patients with myeloproliferative neoplasm-associated myelofibrosis. Leukemia 2020, 35, 1-17. [CrossRef]

128. Wernig, G.; Kharas, M.G.; Okabe, R.; Moore, S.A.; Leeman, D.S.; Cullen, D.E.; Gozo, M.; McDowell, E.P.; Levine, R.L.; Doukas, J.; et al. Efficacy of TG101348, a selective JAK2 inhibitor, in treatment of a murine model of JAK2V617F-induced polycythemia vera. Cancer Cell 2008, 13, 311-320. [CrossRef]

129. Mullally, A.; Lane, S.W.; Ball, B.; Megerdichian, C.; Okabe, R.; Al-Shahrour, F.; Paktinat, M.; Haydu, J.E.; Housman, E.; Lord, A.M.; et al. Physiological Jak2V617F expression causes a lethal myeloproliferative neoplasm with differential effects on hematopoietic stem and progenitor cells. Cancer Cell 2010, 17, 584-596. [CrossRef]

130. Geron, I.; Abrahamsson, A.E.; Barroga, C.F.; Kavalerchik, E.; Gotlib, J.; Hood, J.D.; Durocher, J.; Mak, C.C.; Noronha, G.; Soll, R.M.; et al. Selective inhibition of JAK2-driven erythroid differentiation of polycythemia vera progenitors. Cancer Cell 2008, 13, 321-330. [CrossRef]

131. Lasho, T.L.; Tefferi, A.; Hood, J.D.; Verstovsek, S.; Gilliland, D.G.; Pardanani, A. TG101348, a JAK2-selective antagonist, inhibits primary hematopoietic cells derived from myeloproliferative disorder patients with JAK2V617F, MPLW515K or JAK2 exon 12 mutations as well as mutation negative patients. Leukemia 2008, 22, 1790-1792. [CrossRef]

132. Pardanani, A.; Gotlib, J.R.; Jamieson, C.; Cortes, J.E.; Talpaz, M.; Stone, R.M.; Silverman, M.H.; Gilliland, D.G.; Shorr, J.; Tefferi, A. Safety and efficacy of TG101348, a selective JAK2 inhibitor, in myelofibrosis. J. Clin. Oncol. 2011, 29, 789-796. [CrossRef]

133. Pardanani, A.; Harrison, C.; Cortes, J.E.; Cervantes, F.; Mesa, R.A.; Milligan, D.; Masszi, T.; Mishchenko, E.; Jourdan, E.; Vannucchi, A.M.; et al. Safety and Efficacy of Fedratinib in Patients With Primary or Secondary Myelofibrosis: A Randomized Clinical Trial. JAMA Oncol. 2015, 1, 643-651. [CrossRef]

134. Ogasawara, K.; Xu, C.; Kanamaluru, V.; Palmisano, M.; Krishna, G. Effects of repeated oral doses of ketoconazole on a sequential ascending single oral dose of fedratinib in healthy subjects. Cancer Chemother. Pharmacol. 2020, 85, 899-906. [CrossRef]

135. Harrison, C.N.; Schaap, N.; Vannucchi, A.M.; Kiladjian, J.J.; Tiu, R.V.; Zachee, P.; Jourdan, E.; Winton, E.; Silver, R.T.; Schouten, H.C.; et al. Janus kinase-2 inhibitor fedratinib in patients with myelofibrosis previously treated with ruxolitinib (JAKARTA-2): A single-arm, open-label, non-randomised, phase 2, multicentre study. Lancet Haematol. 2017, 4, e317-e324. [CrossRef]

136. Bewersdorf, J.P.; Jaszczur, S.M.; Afifi, S.; Zhao, J.C.; Zeidan, A.M. Beyond Ruxolitinib: Fedratinib and Other Emergent Treatment Options for Myelofibrosis. Cancer Manag. Res. 2019, 11, 10777-10790. [CrossRef] [PubMed]

137. Hart, S.; Goh, K.C.; Novotny-Diermayr, V.; Hu, C.Y.; Hentze, H.; Tan, Y.C.; Madan, B.; Amalini, C.; Loh, Y.K.; Ong, L.C.; et al. SB1518, a novel macrocyclic pyrimidine-based JAK2 inhibitor for the treatment of myeloid and lymphoid malignancies. Leukemia 2011, 25, 1751-1759. [CrossRef] [PubMed]

138. Hart, S.; Goh, K.C.; Novotny-Diermayr, V.; Tan, Y.C.; Madan, B.; Amalini, C.; Ong, L.C.; Kheng, B.; Cheong, A.; Zhou, J.; et al. Pacritinib (SB1518), a JAK2/FLT3 inhibitor for the treatment of acute myeloid leukemia. Blood Cancer J. 2011, 1, e44. [CrossRef]

139. William, A.D.; Lee, A.C.; Blanchard, S.; Poulsen, A.; Teo, E.L.; Nagaraj, H.; Tan, E.; Chen, D.; Williams, M.; Sun, E.T.; et al. Discovery of the macrocycle 11-(2-pyrrolidin-1-yl-ethoxy)-14,19-dioxa-5,7,26-triaza-tetracyclo[1 9.3.1.1(2,6). 1(8,12)] ]heptacosa1(25),2(26),3,5,8,10,12(27),16,21,23-decaene (SB1518), a potent Janus kinase 2/fms-like tyrosine kinase-3 (JAK2/FLT3) inhibitor for the treatment of myelofibrosis and lymphoma. J. Med. Chem. 2011, 54, 4638-4658. [CrossRef] [PubMed]

140. Komrokji, R.S.; Seymour, J.F.; Roberts, A.W.; Wadleigh, M.; To, L.B.; Scherber, R.; Turba, E.; Dorr, A.; Zhu, J.; Wang, L.; et al. Results of a phase 2 study of pacritinib (SB1518), a JAK2/JAK2(V617F) inhibitor, in patients with myelofibrosis. Blood 2015, 125, 2649-2655. [CrossRef]

141. Jeon, J.Y.; Zhao, Q.; Buelow, D.R.; Phelps, M.; Walker, A.R.; Mims, A.S.; Vasu, S.; Behbehani, G.; Blachly, J.; Blum, W.; et al. Preclinical activity and a pilot phase I study of pacritinib, an oral JAK2/FLT3 inhibitor, and chemotherapy in FLT3-ITD-positive AML. Investig. New Drugs 2020, 38, 340-349. [CrossRef]

142. Verstovsek, S.; Komrokji, R.S. A comprehensive review of pacritinib in myelofibrosis. Future Oncol. 2015, 11, 2819-2830. [CrossRef]

143. Mascarenhas, J.; Hoffman, R.; Talpaz, M.; Gerds, A.T.; Stein, B.; Gupta, V.; Szoke, A.; Drummond, M.; Pristupa, A.; Granston, T.; et al. Pacritinib vs Best Available Therapy, Including Ruxolitinib, in Patients with Myelofibrosis: A Randomized Clinical Trial. JAMA Oncol. 2018, 4, 652-659. [CrossRef]

144. Jayaraman, R.; Pasha, M.K.; Williams, A.; Goh, K.C.; Ethirajulu, K. Metabolism and Disposition of Pacritinib (SB1518), an Orally Active Janus Kinase 2 Inhibitor in Preclinical Species and Humans. Drug Metab. Lett. 2015, 9, 28-47. [CrossRef] 
145. Jensen, K.V.; Cseh, O.; Aman, A.; Weiss, S.; Luchman, H.A. The JAK2/STAT3 inhibitor pacritinib effectively inhibits patientderived GBM brain tumor initiating cells in vitro and when used in combination with temozolomide increases survival in an orthotopic xenograft model. PLoS ONE 2017, 12, e0189670. [CrossRef] [PubMed]

146. Fridman, J.S.; Scherle, P.A.; Collins, R.; Burn, T.C.; Li, Y.; Li, J.; Covington, M.B.; Thomas, B.; Collier, P.; Favata, M.F.; et al. Selective inhibition of JAK1 and JAK2 is efficacious in rodent models of arthritis: Preclinical characterization of INCB028050. J. Immunol. 2010, 184, 5298-5307. [CrossRef] [PubMed]

147. Van Rompaey, L.G.R.; Galien, R.; van der Aar, E.M.; Clement-Lacroix, P.; Nelles, L.; Smets, B.; Lepescheux, L.; Christophe, T.; Conrath, K.; Vandeghinste, N.; et al. Preclinical characterization of GLPG0634, a selective inhibitor of JAK1, for the treatment of inflammatory diseases. J. Immunol. 2013, 191, 3568-3577. [CrossRef] [PubMed]

148. Genovese, M.C.; Kremer, J.; Zamani, O.; Ludivico, C.; Krogulec, M.; Xie, L.; Beattie, S.D.; Koch, A.E.; Cardillo, T.E.; Rooney, T.P.; et al. Baricitinib in Patients with Refractory Rheumatoid Arthritis. N. Engl. J. Med. 2016, 374, 1243-1252. [CrossRef] [PubMed]

149. Winthrop, K.L.; Harigai, M.; Genovese, M.C.; Lindsey, S.; Takeuchi, T.; Fleischmann, R.; Bradley, J.D.; Byers, N.L.; Hyslop, D.L.; Issa, M.; et al. Infections in baricitinib clinical trials for patients with active rheumatoid arthritis. Ann. Rheum. Dis. 2020, 79, 1290-1297. [CrossRef]

150. Mogul, A.; Corsi, K.; McAuliffe, L. Baricitinib: The Second FDA-Approved JAK Inhibitor for the Treatment of Rheumatoid Arthritis. Ann. Pharmacother. 2019, 53, 947-953. [CrossRef] [PubMed]

151. Winthrop, K.L. The emerging safety profile of JAK inhibitors in rheumatic disease. Nat. Rev. Rheumatol. 2017, 13, 320. [CrossRef]

152. Kay, J.; Harigai, M.; Rancourt, J.; Dickson, C.; Melby, T.; Issa, M.; de la Torre, I.; Isaka, Y.; Cardoso, A.; Saifan, C.; et al. Changes in selected haematological parameters associated with JAK1/JAK2 inhibition observed in patients with rheumatoid arthritis treated with baricitinib. RMD Open 2020, 6, e001370. [CrossRef]

153. Scott, I.C.; Hider, S.L.; Scott, D.L. Thromboembolism with Janus Kinase (JAK) Inhibitors for Rheumatoid Arthritis: How Real is the Risk? Drug Saf. 2018, 41, 645-653. [CrossRef]

154. Pardanani, A.; Lasho, T.; Smith, G.; Burns, C.J.; Fantino, E.; Tefferi, A. CYT387, a selective JAK1/JAK2 inhibitor: In vitro assessment of kinase selectivity and preclinical studies using cell lines and primary cells from polycythemia vera patients. Leukemia 2009, 23, 1441-1445. [CrossRef]

155. Pardanani, A.; Laborde, R.R.; Lasho, T.L.; Finke, C.; Begna, K.; Al-Kali, A.; Hogan, W.J.; Litzow, M.R.; Leontovich, A.; Kowalski, M.; et al. Safety and efficacy of CYT387, a JAK1 and JAK2 inhibitor, in myelofibrosis. Leukemia 2013, 27, 1322-1327. [CrossRef]

156. Gupta, V.; Mesa, R.A.; Deininger, M.W.; Rivera, C.E.; Sirhan, S.; Brachmann, C.B.; Collins, H.; Kawashima, J.; Xin, Y.; Verstovsek, S. A phase 1/2, open-label study evaluating twice-daily administration of momelotinib in myelofibrosis. Haematologica 2017, 102, 94-102. [CrossRef]

157. Verstovsek, S.; Courby, S.; Griesshammer, M.; Mesa, R.A.; Brachmann, C.B.; Kawashima, J.; Maltzman, J.D.; Shao, L.; Xin, Y.; Huang, D.; et al. A phase 2 study of momelotinib, a potent JAK1 and JAK2 inhibitor, in patients with polycythemia vera or essential thrombocythemia. Leuk. Res. 2017, 60, 11-17. [CrossRef]

158. Mesa, R.A.; Kiladjian, J.J.; Catalano, J.V.; Devos, T.; Egyed, M.; Hellmann, A.; McLornan, D.; Shimoda, K.; Winton, E.F.; Deng, W.; et al. SIMPLIFY-1: A Phase III Randomized Trial of Momelotinib Versus Ruxolitinib in Janus Kinase Inhibitor-Naive Patients With Myelofibrosis. J. Clin. Oncol. 2017, 35, 3844-3850. [CrossRef] [PubMed]

159. Verstovsek, S.; Chen, C.C.; Egyed, M.; Ellis, M.; Fox, L.; Goh, Y.T.; Gupta, V.; Harrison, C.; Kiladjian, J.J.; Lazaroiu, M.C.; et al MOMENTUM: Momelotinib vs danazol in patients with myelofibrosis previously treated with JAKi who are symptomatic and anemic. Future Oncol. 2021, 17, 1449-1458. [CrossRef] [PubMed]

160. Harrison, C.N.; Vannucchi, A.M.; Platzbecker, U.; Cervantes, F.; Gupta, V.; Lavie, D.; Passamonti, F.; Winton, E.F.; Dong, H.; Kawashima, J.; et al. Momelotinib versus best available therapy in patients with myelofibrosis previously treated with ruxolitinib (SIMPLIFY 2): A randomised, open-label, phase 3 trial. Lancet Haematol. 2018, 5, e73-e81. [CrossRef]

161. Barbie, D.A.; Spira, A.; Kelly, K.; Humeniuk, R.; Kawashima, J.; Kong, S.; Koczywas, M. Phase 1B Study of Momelotinib Combined With Trametinib in Metastatic, Kirsten Rat Sarcoma Viral Oncogene Homolog-Mutated Non-Small-Cell Lung Cancer After Platinum-Based Chemotherapy Treatment Failure. Clin. Lung Cancer 2018, 19, e853-e859. [CrossRef]

162. Padda, S.K.; Reckamp, K.L. Combination of Immunotherapy and Antiangiogenic Therapy in Cancer-a Rational Approach. J. Thorac. Oncol. 2021, 16, 178-182. [CrossRef]

163. Ma, L.; Clayton, J.R.; Walgren, R.A.; Zhao, B.; Evans, R.J.; Smith, M.C.; Heinz-Taheny, K.M.; Kreklau, E.L.; Bloem, L.; Pitou, C.; et al. Discovery and characterization of LY2784544, a small-molecule tyrosine kinase inhibitor of JAK2V617F. Blood Cancer J. 2013, 3, e109. [CrossRef]

164. Verstovsek, S.; Mesa, R.A.; Salama, M.E.; Li, L.; Pitou, C.; Nunes, F.P.; Price, G.L.; Giles, J.L.; D’Souza, D.N.; Walgren, R.A.; et al. A phase 1 study of the Janus kinase 2 (JAK2)(V617F) inhibitor, gandotinib (LY2784544), in patients with primary myelofibrosis, polycythemia vera, and essential thrombocythemia. Leuk. Res. 2017, 61, 89-95. [CrossRef] [PubMed]

165. Berdeja, J.; Palandri, F.; Baer, M.R.; Quick, D.; Kiladjian, J.J.; Martinelli, G.; Verma, A.; Hamid, O.; Walgren, R.; Pitou, C.; et al. Phase 2 study of gandotinib (LY2784544) in patients with myeloproliferative neoplasms. Leuk. Res. 2018, 71, 82-88. [CrossRef] [PubMed]

166. Ito, M.; Yamazaki, S.; Yamagami, K.; Kuno, M.; Morita, Y.; Okuma, K.; Nakamura, K.; Chida, N.; Inami, M.; Inoue, T.; et al. A novel JAK inhibitor, peficitinib, demonstrates potent efficacy in a rat adjuvant-induced arthritis model. J. Pharmacol. Sci. 2017, 133, 25-33. [CrossRef] [PubMed] 
167. Takeuchi, T.; Tanaka, Y.; Tanaka, S.; Kawakami, A.; Song, Y.W.; Chen, Y.H.; Rokuda, M.; Izutsu, H.; Ushijima, S.; Kaneko, Y.; et al. Safety and effectiveness of peficitinib (ASP015K) in patients with rheumatoid arthritis: Interim data (22.7 months mean peficitinib treatment) from a long-term, open-label extension study in Japan, Korea, and Taiwan. Arthritis Res. Ther. 2020, 22, 47. [CrossRef]

168. Astellas. Oral JAK Inhibitor Smyraf®Tablets Approved in Japan for the Treatment of Rheumatoid Arthritis (Including Prevention of Structural Joint Damage) in Patients Who Have an Inadequate Response to Conventional Therapies. 2019. Available online: https:/ / www.astellas.com/system/files/news/2019-03/190326_eg_pefi_approval_final_0.pdf (accessed on 8 September 2021).

169. Levis, M.; Ravandi, F.; Wang, E.S.; Baer, M.R.; Perl, A.; Coutre, S.; Erba, H.; Stuart, R.K.; Baccarani, M.; Cripe, L.D.; et al. Results from a randomized trial of salvage chemotherapy followed by lestaurtinib for patients with FLT3 mutant AML in first relapse. Blood 2011, 117, 3294-3301. [CrossRef]

170. Hexner, E.O.; Mascarenhas, J.; Prchal, J.; Roboz, G.J.; Baer, M.R.; Ritchie, E.K.; Leibowitz, D.; Demakos, E.P.; Miller, C.; Siuty, J.; et al. Phase I dose escalation study of lestaurtinib in patients with myelofibrosis. Leuk. Lymphoma 2015, 56, 2543-2551. [CrossRef]

171. Collins, C.; Carducci, M.A.; Eisenberger, M.A.; Isaacs, J.T.; Partin, A.W.; Pili, R.; Sinibaldi, V.J.; Walczak, J.S.; Denmeade, S.R. Preclinical and clinical studies with the multi-kinase inhibitor CEP-701 as treatment for prostate cancer demonstrate the inadequacy of PSA response as a primary endpoint. Cancer Biol. Ther. 2007, 6, 1360-1367. [CrossRef]

172. Furumoto, Y.; Gadina, M. The arrival of JAK inhibitors: Advancing the treatment of immune and hematologic disorders. BioDrugs 2013, 27, 431-438. [CrossRef]

173. Ghoreschi, K.; Jesson, M.I.; Li, X.; Lee, J.L.; Ghosh, S.; Alsup, J.W.; Warner, J.D.; Tanaka, M.; Steward-Tharp, S.M.; Gadina, M.; et al. Modulation of innate and adaptive immune responses by tofacitinib (CP-690,550). J. Immunol. 2011, 186, 4234-4243. [CrossRef] [PubMed]

174. Seol, M.A.; Kim, J.H.; Oh, K.; Kim, G.; Seo, M.W.; Shin, Y.K.; Sim, J.H.; Shin, H.M.; Seo, B.Y.; Lee, D.S.; et al. Interleukin-7 Contributes to the Invasiveness of Prostate Cancer Cells by Promoting Epithelial-Mesenchymal Transition. Sci. Rep. 2019, 9, 6917. [CrossRef] [PubMed]

175. Sandborn, W.J.; Ghosh, S.; Panes, J.; Vranic, I.; Su, C.; Rousell, S.; Niezychowski, W.; Study, A.I. Tofacitinib, an oral Janus kinase inhibitor, in active ulcerative colitis. N. Engl. J. Med. 2012, 367, 616-624. [CrossRef]

176. Verstovsek, S.; Manshouri, T.; Quintas-Cardama, A.; Harris, D.; Cortes, J.; Giles, F.J.; Kantarjian, H.; Priebe, W.; Estrov, Z. WP1066, a novel JAK2 inhibitor, suppresses proliferation and induces apoptosis in erythroid human cells carrying the JAK2 V617F mutation. Clin. Cancer Res. 2008, 14, 788-796. [CrossRef]

177. Tsujita, Y.; Horiguchi, A.; Tasaki, S.; Isono, M.; Asano, T.; Ito, K.; Asano, T.; Mayumi, Y.; Kushibiki, T. STAT3 inhibition by WP1066 suppresses the growth and invasiveness of bladder cancer cells. Oncol. Rep. 2017, 38, 2197-2204. [CrossRef]

178. Horiguchi, A.; Asano, T.; Kuroda, K.; Sato, A.; Asakuma, J.; Ito, K.; Hayakawa, M.; Sumitomo, M.; Asano, T. STAT3 inhibitor WP1066 as a novel therapeutic agent for renal cell carcinoma. Br. J. Cancer 2010, 102, 1592-1599. [CrossRef]

179. Howard, S.; Berdini, V.; Boulstridge, J.A.; Carr, M.G.; Cross, D.M.; Curry, J.; Devine, L.A.; Early, T.R.; Fazal, L.; Gill, A.L.; et al. Fragment-based discovery of the pyrazol-4-yl urea (AT9283), a multitargeted kinase inhibitor with potent aurora kinase activity. J. Med. Chem. 2009, 52, 379-388. [CrossRef]

180. Qi, W.; Liu, X.; Cooke, L.S.; Persky, D.O.; Miller, T.P.; Squires, M.; Mahadevan, D. AT9283, a novel aurora kinase inhibitor, suppresses tumor growth in aggressive B-cell lymphomas. Int. J. Cancer 2012, 130, 2997-3005. [CrossRef] [PubMed]

181. WP1066. (n.d.). Moleculin Biotech. 2020. Available online: https://www.moleculin.com/technology/wp1066/ (accessed on 23 June 2021).

182. Atallah, E.; Verstovsek, S. Prospect of JAK2 inhibitor therapy in myeloproliferative neoplasms. Expert Rev. Anticancer Ther. 2009, 9, 663-670. [CrossRef]

183. Lakings, D.B. Atiprimod (AnorMED). IDrugs 2000, 3, 329-335. [PubMed]

184. Quintas-Cardama, A.; Manshouri, T.; Estrov, Z.; Harris, D.; Zhang, Y.; Gaikwad, A.; Kantarjian, H.M.; Verstovsek, S. Preclinical characterization of atiprimod, a novel JAK2 AND JAK3 inhibitor. Investig. New Drugs 2011, 29, 818-826. [CrossRef] [PubMed]

185. Manshouri, T.; Golemovic, M.; Kantarjian, H.M.M.; Cortes, J.E.; Zhang, Y.; Priebe, W.; Estrov, Z.; Vrstovsek, S. Atiprimod inhibits the JAK-STAT pathway and induces apootosis in human cells carrying the JAK2(V617F) or JAK3 mutation. Blood 2007, 110, 1040a-1041a. [CrossRef]

186. Wang, M.; Zhang, L.A.; Han, X.H.; Yang, J.; Qian, J.F.; Hong, S.Y.; Samaniego, F.; Rornaguera, J.; Yi, Q. Atiprimod inhibits the growth of mantle cell lymphoma in vitro and in vivo and induces apoptosis via activating the mitochondrial pathways. Blood 2007, 109, 5455-5462. [CrossRef]

187. Amit-Vazina, M.; Shishodia, S.; Harris, D.; Van, Q.; Wang, M.; Weber, D.; Alexanian, R.; Talpaz, M.; Aggarwal, B.B.; Estrov, Z. Atiprimod blocks STAT3 phosphorylation and induces apoptosis in multiple myeloma cells. Br. J. Cancer 2005, 93, 70-80. [CrossRef]

188. Chan, D.; Koren-Michowitz, M. Update on JAK2 Inhibitors in Myeloproliferative Neoplasm. Ther. Adv. Hematol. 2011, 2, 61-71. [CrossRef]

189. Nakaya, Y.; Naito, H.; Homan, J.; Sugahara, S.; Horio, T.; Niwa, T.; Shide, K.; Shimoda, K. Preferential Inhibition of An Activated Form of Janus Kinase 2 (JAK2) by a Novel JAK2 Inhibitor, NS-018. Blood 2010, 116, 1672. [CrossRef]

190. Shide, K.; Nakaya, Y.; Kameda, T.; Shimoda, H.; Hidaka, T.; Kubuki, Y.; Katayose, K.; Matsunaga, T.; Homan, J.; Kotera, T.; et al. NS-018, a Potent Novel JAK2 Inhibitor, Effectively Treats Murine MPN Induced by the Janus Kinase 2 (JAK2) V617F Mutant. Blood 2010, 116, 1671-1672. [CrossRef] 
191. Holladay, M.W.; Setti, E. Optically Active Pyrazolylaminoquinazoline, and Pharmaceutical Compositions and Methods of Use Thereof. US patent No. US8703943, 22 April 2014.

192. Lipka, D.B.; Hoffmann, L.S.; Heidel, F.; Markova, B.; Blum, M.C.; Breitenbuecher, F.; Kasper, S.; Kindler, T.; Levine, R.L.; Huber, C.; et al. LS104, a non-ATP-competitive small-molecule inhibitor of JAK2, is potently inducing apoptosis in JAK2V617F-positive cells. Mol. Cancer Ther. 2008, 7, 1176-1184. [CrossRef] [PubMed]

193. Liu, J.; Lv, B.; Yin, H.; Zhu, X.; Wei, H.; Ding, Y. A Phase I, Randomized, Double-Blind, Placebo-Controlled, Single Ascending Dose, Multiple Ascending Dose and Food Effect Study to Evaluate the Tolerance, Pharmacokinetics of Jaktinib, a New Selective Janus Kinase Inhibitor in Healthy Chinese Volunteers, CLINICAL TRIAL. Front. Pharmacol. 2020, 11, 604314. [CrossRef]

194. Santo, L.; Hideshima, T.; Cirstea, D.; Bandi, M.; Nelson, E.A.; Gorgun, G.; Rodig, S.; Vallet, S.; Pozzi, S.; Patel, K.; et al. Antimyeloma activity of a multitargeted kinase inhibitor, AT9283, via potent Aurora kinase and STAT3 inhibition either alone or in combination with lenalidomide. Clin. Cancer Res. 2011, 17, 3259-3271. [CrossRef] [PubMed]

195. Foran, J.; Ravandi, F.; Wierda, W.; Garcia-Manero, G.; Verstovsek, S.; Kadia, T.; Burger, J.; Yule, M.; Langford, G.; Lyons, J.; et al. A phase I and pharmacodynamic study of AT9283, a small-molecule inhibitor of aurora kinases in patients with relapsed/refractory leukemia or myelofibrosis. Clin. Lymphoma Myeloma Leuk. 2014, 14, 223-230. [CrossRef] [PubMed]

196. Guo, A.; Lu, P.; Coffey, G.; Conley, P.; Pandey, A.; Wang, L.Y. Dual SYK/JAK inhibition overcomes ibrutinib resistance in chronic lymphocytic leukemia: Cerdulatinib, but not ibrutinib, induces apoptosis of tumor cells protected by the microenvironment. Oncotarget 2017, 8, 12953-12967. [CrossRef] [PubMed]

197. Traves, P.G.; Murray, B.; Campigotto, F.; Galien, R.; Meng, A.; Di Paolo, J.A. JAK selectivity and the implications for clinical inhibition of pharmacodynamic cytokine signalling by filgotinib, upadacitinib, tofacitinib and baricitinib. Ann. Rheum. Dis. 2021, 80, 865-875. [CrossRef] [PubMed]

198. Shien, K.; Papadimitrakopoulou, V.A.; Ruder, D.; Behrens, C.; Shen, L.; Kalhor, N.; Song, J.; Lee, J.J.; Wang, J.; Tang, X.; et al. JAK1/STAT3 Activation through a Proinflammatory Cytokine Pathway Leads to Resistance to Molecularly Targeted Therapy in Non-Small Cell Lung Cancer. Mol. Cancer Ther. 2017, 16, 2234-2245. [CrossRef]

199. Dhillon, S.; Keam, S.J. Filgotinib: First Approval. Drugs 2020, 80, 1987-1997. [CrossRef]

200. European Medicine Agency. Filgotinib (Jyseleca®): Summary of product characteristics. Available online: https://www.ema. europa.eu/en/medicines/human/EPAR/jyseleca (accessed on 30 September 2020).

201. Eisai. Jyseleca ${ }^{\circledR}$ (Filgotinib) Approved in Japan for Rheumatoid Arthritis [Press Release]. Available online: https://www.eisai. com/news/2020/news202075.html (accessed on 25 September 2020).

202. Gilead Sciences Inc. Gilead Receives Complete Response Letter for Filgotinib for the Treatment of Moderately to Severely Active Rheumatoid Arthritis [Press Release]. Available online: https:/ /www.gilead.com/news-and-press/press-room/pressreleases / 2020/8/gilead-receives-complete-response-letter-for-filgotinib-for-the-treatment-of-moderately-to-severely-activerheumatoid-arthritis (accessed on 18 August 2020).

203. Genovese, M.C.; Kalunian, K.; Gottenberg, J.E.; Mozaffarian, N.; Bartok, B.; Matzkies, F.; Gao, J.; Guo, Y.; Tasset, C.; Sundy, J.S.; et al. Effect of Filgotinib vs Placebo on Clinical Response in Patients With Moderate to Severe Rheumatoid Arthritis Refractory to Disease-Modifying Antirheumatic Drug Therapy: The FINCH 2 Randomized Clinical Trial. JAMA 2019, 322, 315-325. [CrossRef]

204. Mahajan, S.; Hogan, J.K.; Shlyakhter, D.; Oh, L.; Salituro, F.G.; Farmer, L.; Hoock, T.C. VX-509 (decernotinib) is a potent and selective janus kinase 3 inhibitor that attenuates inflammation in animal models of autoimmune disease. J. Pharmacol. Exp. Ther. 2015, 353, 405-414. [CrossRef]

205. Genovese, M.C.; van Vollenhoven, R.F.; Pacheco-Tena, C.; Zhang, Y.; Kinnman, N. VX-509 (Decernotinib), an Oral Selective JAK-3 Inhibitor, in Combination With Methotrexate in Patients With Rheumatoid Arthritis. Arthritis Rheumatol. 2016, 68, 46-55. [CrossRef]

206. Li, Z.; Xu, M.; Xing, S.; Ho, W.T.; Ishii, T.; Li, Q.; Fu, X.; Zhao, Z.J. Erlotinib effectively inhibits JAK2V617F activity and polycythemia vera cell growth. J. Biol. Chem. 2007, 282, 3428-3432. [CrossRef]

207. Nabhan, C.; Lestingi, M.T.; Galvez, A.; Tolzien, K.; Kelby, K.S.; Tsarwhas, D.; Newman, S.; Bitran, D.J. Erlotinib Has Moderate Single-agent Activity in Chemotherapy-naïve Castration-resistant Prostate Cancer: Final Results of a Phase II Trial. Urology 2009, 74, 665-671. [CrossRef]

208. Chmielinska, J.J.; Kramer, J.H.; Mak, I.T.; Spurney, C.F.; Weglicki, W.B. Substance P receptor blocker, aprepitant, inhibited cutaneous and other neurogenic inflammation side effects of the EGFR1-TKI, erlotinib. Mol. Cell Biochem. 2020, 465, 175-185. [CrossRef] [PubMed]

209. Rambaldi, A.; Dellacasa, C.M.; Finazzi, G.; Carobbio, A.; Ferrari, M.L.; Guglielmelli, P.; Gattoni, E.; Salmoiraghi, S.; Finazzi, M.C.; Di Tollo, S.; et al. A pilot study of the Histone-Deacetylase inhibitor Givinostat in patients with JAK2V617F positive chronic myeloproliferative neoplasms. Br. J. Haematol. 2010, 150, 446-455. [CrossRef] [PubMed]

210. Savino, A.M.; Sarno, J.; Trentin, L.; Vieri, M.; Fazio, G.; Bardini, M.; Bugarin, C.; Fossati, G.; Davis, K.L.; Gaipa, G.; et al. The histone deacetylase inhibitor givinostat (ITF2357) exhibits potent anti-tumor activity against CRLF2-rearranged BCP-ALL. Leukemia 2017, 31, 2365-2375. [CrossRef]

211. Zhai, D.; Deng, W.; Huang, Z.; Rogers, E.; Cui, J.J. Abstract 2132: The novel, rationally-designed, ALK/SRC inhibitor TPX-0005 overcomes multiple acquired resistance mechanisms to current ALK inhibitors. Cancer Res. 2016, 76, 2016-2132. [CrossRef] 
212. Karachaliou, N.; Chaib, I.; Cardona, A.F.; Berenguer, J.; Bracht, J.W.P.; Yang, J.; Cai, X.; Wang, Z.; Hu, C.; Drozdowskyj, A.; et al. Common Co-activation of AXL and CDCP1 in EGFR-mutation-positive Non-smallcell Lung Cancer Associated With Poor Prognosis. EBioMedicine 2018, 29, 112-127. [CrossRef] [PubMed]

213. Drilon, A.; Ou, S.H.I.; Cho, B.C.; Kim, D.W.; Lees, J.; Lin, J.J.; Zhu, V.W.; Ahns, M.J.; Camidge, D.R.; Nguyen, J.; et al. Repotrectinib (TPX-0005) Is a Next-Generation ROS1/TRK/ALK Inhibitor That Potently Inhibit ROS1/TRK/ALK Solvent-Front Mutations Cancer Discov. 2018, 8, 1227-1236. [CrossRef]

214. Wu, J.; Yuan, Y.; Long Priel, D.A.; Fink, D.; Peer, C.J.; Sissung, T.M.; Su, Y.T.; Pang, Y.; Yu, G.; Butler, M.K.; et al. Phase I Study of Zotiraciclib in Combination with Temozolomide for Patients with Recurrent High-grade Astrocytomas. Clin. Cancer Res. 2021, 27, 3298-3306. [CrossRef] [PubMed]

215. William, A.D.; Lee, A.C.; Goh, K.C.; Blanchard, S.; Poulsen, A.; Teo, E.L.; Nagaraj, H.; Lee, C.P.; Wang, H.; Williams, M.; et al. Discovery of kinase spectrum selective macrocycle (16E)-14-methyl-20-oxa-5,7,14,26-tetraazatetracyclo[19.3.1.1(2,6).1(8,12)] heptaco sa-1(25),2(26),3,5,8(27),9,11,16,21,23-decaene (SB1317/TG02), a potent inhibitor of cyclin dependent kinases (CDKs), Janus kinase 2 (JAK2), and fms-like tyrosine kinase-3 (FLT3) for the treatment of cancer. J. Med. Chem. 2012, 55, 169-196. [CrossRef]

216. Baffert, F.; Regnier, C.H.; De Pover, A.; Pissot-Soldermann, C.; Tavares, G.A.; Blasco, F.; Brueggen, J.; Chene, P.; Drueckes, P.; Erdmann, D.; et al. Potent and selective inhibition of polycythemia by the quinoxaline JAK2 inhibitor NVP-BSK805. Mol. Cancer Ther. 2010, 9, 1945-1955. [CrossRef]

217. Stump, K.L.; Lu, L.D.; Dobrzanski, P.; Serdikoff, C.; Gingrich, D.E.; Dugan, B.J.; Angeles, T.S.; Albom, M.S.; Ator, M.A.; Dorsey, B.D.; et al. A highly selective, orally active inhibitor of Janus kinase 2, CEP-33779, ablates disease in two mouse models of rheumatoid arthritis. Arthritis Res. Ther. 2011, 13, R68. [CrossRef] [PubMed]

218. Seavey, M.M.; Lu, L.D.; Stump, K.L.; Wallace, N.H.; Hockeimer, W.; O’Kane, T.M.; Ruggeri, B.A.; Dobrzanski, P. Therapeutic efficacy of CEP-33779, a novel selective JAK2 inhibitor, in a mouse model of colitis-induced colorectal cancer. Mol. Cancer Ther. 2012, 11, 984-993. [CrossRef] [PubMed]

219. Pardanani, A.; Hood, J.; Lasho, T.; Levine, R.L.; Martin, M.B.; Noronha, G.; Finke, C.; Mak, C.C.; Mesa, R.; Zhu, H.; et al. TG101209, a small molecule JAK2-selective kinase inhibitor potently inhibits myeloproliferative disorder-associated JAK2V617F and MPLW515L/K mutations. Leukemia 2007, 21, 1658-1668. [CrossRef]

220. Pardanani, A.; Hood, J.; Lasho, T.; Noronha, G.; Finke, C.; Mak, C.C.; Mesa, R.; Zhu, H.; Soll, R.; Tefferi, A. TG101209, a selective JAK2 kinase inhibitor, suppresses endogenous and cytokine-supported colony formation from hematopoietic progenitors carrying JAK2V617F or MPLW515K/L mutations. Blood 2006, 108, 758a. [CrossRef]

221. Sun, Y.; Moretti, L.; Giacalone, N.J.; Schleicher, S.; Speirs, C.K.; Carbone, D.P.; Lu, B. Inhibition of JAK2 signaling by TG101209 enhances radiotherapy in lung cancer models. J. Thorac. Oncol. 2011, 6, 699-706. [CrossRef] [PubMed]

222. Cheng, Z.; Yi, Y.; Xie, S.; Yu, H.; Peng, H.; Zhang, G. The effect of the JAK2 inhibitor TG101209 against T cell acute lymphoblastic leukemia (T-ALL) is mediated by inhibition of JAK-STAT signaling and activation of the crosstalk between apoptosis and autophagy signaling. Oncotarget 2017, 8, 106753-106763. [CrossRef] [PubMed]

223. Ikezoe, T.; Kojima, S.; Furihata, M.; Yang, J.; Nishioka, C.; Takeuchi, A.; Isaka, M.; Koeffler, H.P.; Yokoyama, A. Expression of p-JAK2 predicts clinical outcome and is a potential molecular target of acute myelogenous leukemia. Int. J. Cancer 2011, 129, 2512-2521. [CrossRef]

224. Gozgit, J.M.; Bebernitz, G.; Patil, P.; Ye, M.; Parmentier, J.; Wu, J.; Su, N.; Wang, T.; Ioannidis, S.; Davies, A.; et al. Effects of the JAK2 inhibitor, AZ960, on Pim/BAD/BCL-xL survival signaling in the human JAK2 V617F cell line SET-2. J. Biol. Chem. 2008, 283, 32334-32343. [CrossRef]

225. Florian, R.; Greten, M.K. Peering into the aftermath: JAKi rips STAT3 in cancer. Nat. Med. 2010, 16, $1085-1087$.

226. Shiels, M.S.; Pfeiffer, R.M.; Gail, M.H.; Hall, H.I.; Li, J.; Chaturvedi, A.K.; Bhatia, K.; Uldrick, T.S.; Yarchoan, R.; Goedert, J.J.; et al. Cancer burden in the HIV-infected population in the United States. J. Natl. Cancer Inst. 2011, 103, 753-762. [CrossRef]

227. Tvorogov, D.; Thomas, D.; Liau, N.P.D.; Dottore, M.; Barry, E.F.; Lathi, M.; Kan, W.L.; Hercus, T.R.; Stomski, F.; Hughes, T.P.; et al. Accumulation of JAK activation loop phosphorylation is linked to type I JAK inhibitor withdrawal syndrome in myelofibrosis. Sci. Adv. 2018, 4, eaat3834. [CrossRef]

228. Jatiani, S.S.; Cosenza, S.C.; Reddy, M.V.; Ha, J.H.; Baker, S.J.; Samanta, A.K.; Olnes, M.J.; Pfannes, L.; Sloand, E.M.; Arlinghaus, R.B.; et al. A Non-ATP-Competitive Dual Inhibitor of JAK2 and BCR-ABL Kinases: Elucidation of a Novel Therapeutic Spectrum Based on Substrate Competitive Inhibition. Genes Cancer 2010, 1, 331-345. [CrossRef]

229. Samanta, A.K.; Chakraborty, S.N.; Wang, Y.; Schlette, E.; Reddy, E.P.; Arlinghaus, R.B. Destabilization of Bcr-Abl/Jak2 Network by a Jak2 / Abl Kinase Inhibitor ON044580 Overcomes Drug Resistance in Blast Crisis Chronic Myelogenous Leukemia (CML). Genes Cancer 2010, 1, 346-359. [CrossRef]

230. Hu, M.; Xu, C.; Yang, C.; Zuo, H.; Chen, C.; Zhang, D.; Shi, G.; Wang, W.; Shi, J.; Zhang, T. Discovery and evaluation of ZT55, a novel highly-selective tyrosine kinase inhibitor of JAK2V617F against myeloproliferative neoplasms. J. Exp. Clin. Cancer Res. 2019, 38, 1-12. [CrossRef] [PubMed]

231. Hedvat, M.; Huszar, D.; Herrmann, A.; Gozgit, J.M.; Schroeder, A.; Sheehy, A.; Buettner, R.; Proia, D.; Kowolik, C.M.; Xin, H.; et al. The JAK2 inhibitor AZD1480 potently blocks Stat3 signaling and oncogenesis in solid tumors. Cancer Cell 2009, 16, 487-497. [CrossRef] [PubMed] 
232. Scuto, A.; Krejci, P.; Popplewell, L.; Wu, J.; Wang, Y.; Kujawski, M.; Kowolik, C.; Xin, H.; Chen, L.; Wang, Y.; et al. The novel JAK inhibitor AZD1480 blocks STAT3 and FGFR3 signaling, resulting in suppression of human myeloma cell growth and survival. Leukemia 2011, 25, 538-550. [CrossRef] [PubMed]

233. Derenzini, E.; Lemoine, M.; Buglio, D.; Katayama, H.; Ji, Y.; Davis, R.E.; Sen, S.; Younes, A. The JAK inhibitor AZD1480 regulates proliferation and immunity in Hodgkin lymphoma. Blood Cancer J. 2011, 1, e46. [CrossRef]

234. Forsyth, T.; Kearney, P.C.; Kim, B.G.; Johnson, H.W.; Aay, N.; Arcalas, A.; Brown, D.S.; Chan, V.; Chen, J.; Du, H.; et al. SAR and in vivo evaluation of 4-aryl-2-aminoalkylpyrimidines as potent and selective Janus kinase 2 (JAK2) inhibitors. Bioorg Med. Chem. Lett. 2012, 22, 7653-7658. [CrossRef]

235. Verstovsek, S.; Tam, C.S.; Wadleigh, M.; Sokol, L.; Smith, C.C.; Bui, L.A.; Song, C.; Clary, D.O.; Olszynski, P.; Cortes, J.; et al. Phase I evaluation of XL019, an oral, potent, and selective JAK2 inhibitor. Leuk. Res. 2014, 38, 316-322. [CrossRef]

236. Pardanani, A.; Roberts, A.W.; Seymour, J.F.; Burbury, K.; Verstovsek, S.; Kantarjian, H.M.; Begna, K.; Yoshitsugu, H.; Gestone, T.A.; Phillips, P.; et al. BMS-911543, A Selective JAK2 Inhibitor: A Multicenter Phase 1/2a Study In Myelofibrosis. Blood 2013, 122, 664. [CrossRef]

237. Wan, H.; Schroeder, G.M.; Hart, A.C.; Inghrim, J.; Grebinski, J.; Tokarski, J.S.; Lorenzi, M.V.; You, D.; McDevitt, T.; Penhallow, B.; et al. Discovery of a Highly Selective JAK2 Inhibitor, BMS-911543, for the Treatment of Myeloproliferative Neoplasms. ACS Med. Chem. Lett. 2015, 6, 850-855. [CrossRef]

238. Purandare, A.V.; McDevitt, T.M.; Wan, H.; You, D.; Penhallow, B.; Han, X.; Vuppugalla, R.; Zhang, Y.; Ruepp, S.U.; Trainor, G.L.; et al. Characterization of BMS-911543, a functionally selective small-molecule inhibitor of JAK2. Leukemia 2012, 26, 280-288. [CrossRef]

239. Martens, S.; Goossens, V.; Devisscher, L.; Hofmans, S.; Claeys, P.; Vuylsteke, M.; Takahashi, N.; Augustyns, K.; Vandenabeele, P. RIPK1-dependent cell death: A novel target of the Aurora kinase inhibitor Tozasertib (VX-680). Cell Death Dis. $2018,9,211$. [CrossRef]

240. Harrington, E.A.; Bebbington, D.; Moore, J.; Rasmussen, R.K.; Ajose-Adeogun, A.O.; Nakayama, T.; Graham, J.A.; Demur, C.; Hercend, T.; Diu-Hercend, A.; et al. VX-680, a potent and selective small-molecule inhibitor of the Aurora kinases, suppresses tumor growth in vivo. Nat. Med. 2004, 10, 262-267. [CrossRef] [PubMed]

241. Arlot-Bonnemains, Y.; Baldini, E.; Martin, B.; Delcros, J.G.; Toller, M.; Curcio, F.; Ambesi-Impiombato, F.S.; D'Armiento, M.; Ulisse, S. Effects of the Aurora kinase inhibitor VX-680 on anaplastic thyroid cancer-derived cell lines. Endocr. Relat. Cancer 2008, 15, 559-568. [CrossRef] [PubMed]

242. Salah, E.; Ugochukwu, E.; Barr, A.J.; von Delft, F.; Knapp, S.; Elkins, J.M. Crystal structures of ABL-related gene (ABL2) in complex with imatinib, tozasertib (VX-680), and a type I inhibitor of the triazole carbothioamide class. J. Med. Chem. 2011, 54, 2359-2367. [CrossRef] [PubMed] 